\title{
Environmental Implications of Increased Biomass Energy Use
}

Final Report

T.R. Miles, Sr.

T.R. Miles, Jr.

Consulting Design Engineers

Portland, OR

NREL technical monitor: R. Overend

National Renewable Energy Laboratory

(formerly the Solar Energy Research Institute)

1617 Cole Boulevard

Golden, Colorado 80401-3393

A Division of Midwest Research Institute Operated for the U.S. Department of Energy under Contract No. DE-AC02-83CH10093

Prepared under task no. BP111010

March 1992 
On September 16, 1991, the Solar Energy Research Instltute was designated a natlonal laboratory, and Its name was changed
to the Natlonal Renewable Energy Laboratory.

\section{NOTICE}

This report was prepared as an account of work sponsored by an agency of the United States government. Neither the United States government nor any agency thereof, nor any of their employees, makes any warranty, express or implied, or assumes any legal liability or responsibility for the accuracy, completeness, or usefulness of any information, apparatus, product, or process disclosed, or represents that its use would not infringe privately owned rights. Reference herein to any specific commercial product, process, or service by trade name, trademark, manufacturer, or otherwise does not necessarily constitute or imply its endorsement, recommendation, or favoring by the United States government or any agency thereof. The views and opinions of authors expressed herein do not necessarily state or reflect those of the United States government or any agency thereof.

Printed in the United States of America

Available from:

National Technical Information Service

U.S. Department of Commerce

5285 Port Royal Road

Springfield, VA 22161

Price: Microfiche A01

Printed Copy A04

Codes are used for pricing all publications. The code is determined by the number of pages in the publication. Information pertaining to the pricing codes can be found in the current issue of the following publications which are generally available in most libraries: Energy Research Abstracts (ERA); Government Reports Announcements and Index (GRA and I); Scientific and Technical Abstract Reports (STAR); and publication NTIS-PR-360 available from NTIS at the above address. 


\section{Acknowledgments}

This review was developed through the cooperative contributions of Pacific Gas and Electric Company, the National Renewable Energy Laboratory (NREL, formerly the Solar Energy Research Institute), and the Western Regional Biomass Program of the U.S. Department of Energy. Several individuals and organizations contributed to this review through participation at workshops and individual comments. Drafts were prepared for discussion at a biomass workshop dedicated to the use of power for electric utilities in Tampa, Florida, and at a national bioenergy meeting in Coeur D'Alene, Idaho. 


\section{Contents}

Executive Summary $\ldots \ldots \ldots \ldots \ldots \ldots \ldots \ldots \ldots \ldots \ldots \ldots \ldots \ldots \ldots \ldots \ldots$

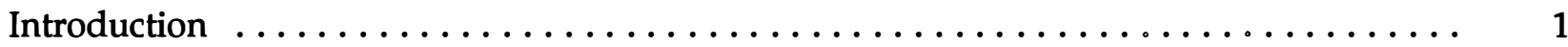

Biomass Resources and Energy Demand $\ldots \ldots \ldots \ldots \ldots \ldots \ldots \ldots \ldots \ldots \ldots \ldots$

Energy Consumption and Future Biofuel Demand $\ldots \ldots \ldots \ldots \ldots \ldots \ldots$

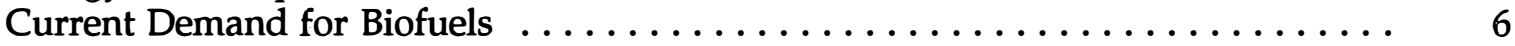

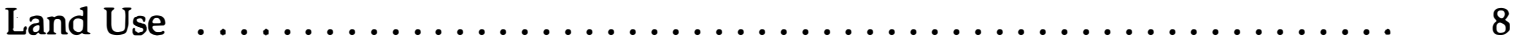

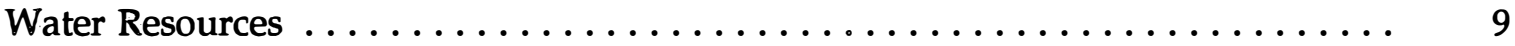

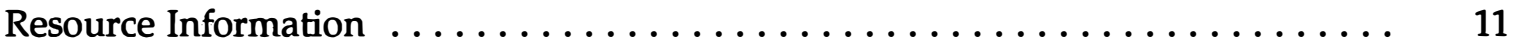

DOE Regional Programs . . . . . . . . . . . 12

Biomass Fuels: Their Occurrence and Suitability $\ldots \ldots \ldots \ldots \ldots \ldots \ldots \ldots$

Wood Residues ................................. 15

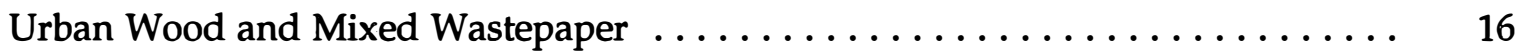

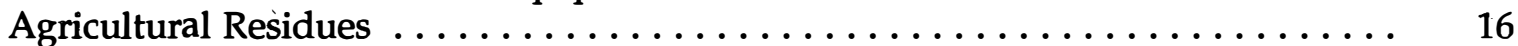

Energy Crops . . . . . . . . . . . . 17

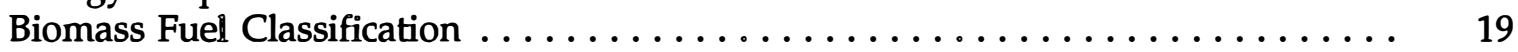

Environmental Implications of Increased Biomass Use $\ldots \ldots \ldots \ldots \ldots \ldots \ldots \ldots \ldots$

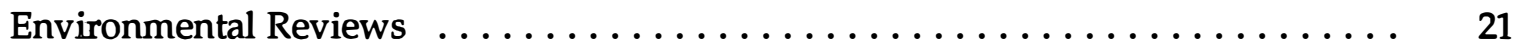

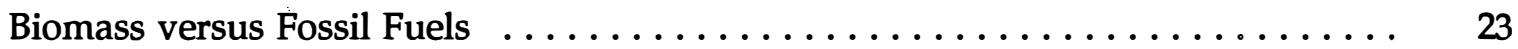

Production and Harvesting of Biomass Feedstocks . . . . . . . . . . . 25

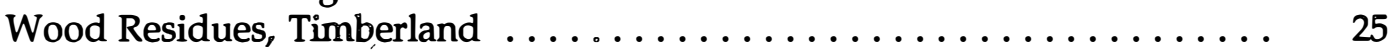

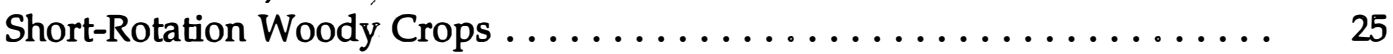

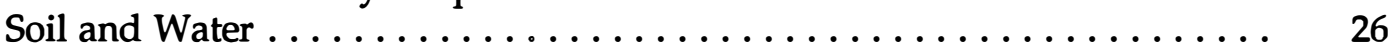

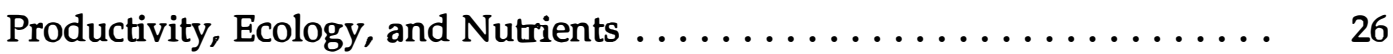

Wildlife Habitats and the Natural Environment $\ldots \ldots \ldots \ldots \ldots \ldots 27$

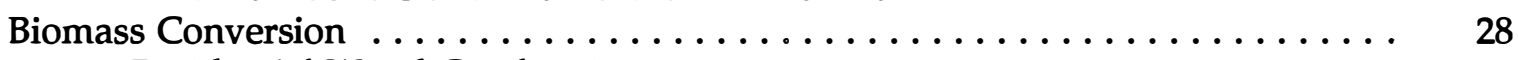

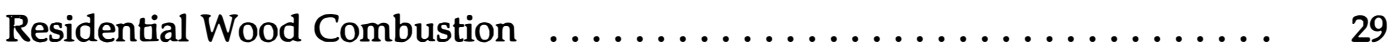

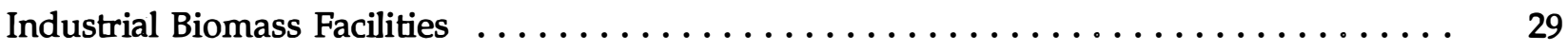

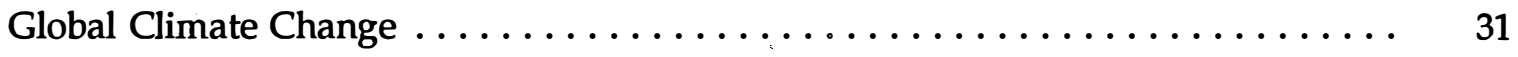

Conclusions and Recommendations $\ldots \ldots \ldots \ldots \ldots \ldots \ldots \ldots \ldots \ldots \ldots \ldots \ldots$

References Cited and Recommended Reading $\ldots \ldots \ldots \ldots \ldots \ldots \ldots \ldots$ 


\section{Figures}

Figure

$\underline{\text { Page }}$

1. Factors influencing selection of a resource/technology $\ldots \ldots \ldots \ldots \ldots \ldots \ldots$

2. Potential U.S. biofuel resources $(2000) \ldots \ldots \ldots \ldots \ldots \ldots \ldots \ldots \ldots \ldots \ldots$

3. Wood energy use $(1972,1987) \ldots \ldots \ldots \ldots \ldots \ldots \ldots \ldots \ldots \ldots \ldots \ldots$

4. Sources of U.S. energy $(1987) \ldots \ldots \ldots \ldots \ldots \ldots \ldots \ldots \ldots \ldots \ldots \ldots$

5. Current biomass consumption and U.S. DOE goals for $2030 \ldots \ldots \ldots \ldots \ldots$

6. Biomass electricity generation by state $(1989) \ldots \ldots \ldots \ldots \ldots \ldots \ldots \ldots \ldots$

7. Demand for electricity and natural gas in quads $(2030) \ldots \ldots \ldots \ldots \ldots$

8. Cropland available for biomass energy production $(2030) \ldots \ldots \ldots \ldots \ldots$

9. Primary energy potentially available from cropland in

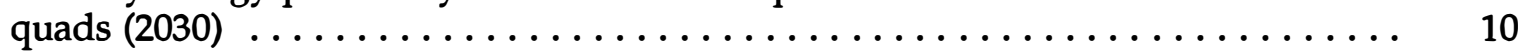

10. DOE regional biomass programs $\ldots \ldots \ldots \ldots \ldots \ldots \ldots \ldots \ldots \ldots \ldots \ldots$

11. Species for evaluation of short-rotation woody crops $\ldots \ldots \ldots \ldots \ldots$

12. Environmental considerations associated with biomass use . . . . . . . . . 30

\section{Tables}

Table

$\underline{\text { Page }}$

1. Recoverable Energy From Biofuels $\ldots \ldots \ldots \ldots \ldots \ldots \ldots \ldots \ldots \ldots \ldots$

2. Environmental Topics in DOE Regional Program Studies $\ldots \ldots \ldots \ldots \ldots \ldots \ldots \ldots$

3. Environmental Topics Important to Increased Biomass Use $\ldots \ldots \ldots \ldots \ldots$

4. Environmental Risks Associated with Biomass Energy $\ldots \ldots \ldots \ldots \ldots$

5. $\quad$ Suggested Negative Impacts Associated with Biomass

Utilization Scaled Very High $(\mathrm{VH})$ to Very Low (VL) $\ldots \ldots \ldots \ldots \ldots \ldots \ldots$

6. Plant and Animal Species Listed as Threatened or

Endangered, by DOE Region . . . . . . . . . . . . . . . . . . 27

7. Environmental Issues for a Biomass Power Plant

in Order of Importance . . . . . . . . . . . . . . . . . . . . . . 31 


\section{Executive Summary}

Increasing the use of biomass for electric power production will depend not only on the supply availability, but also on the degree to which the entire fuel cycle is sustainable. In the short term, an approximate measure of the sustainability is the environmental impact. This report examines all elements of the biomass to electric power production cycle in terms of the known environmental impacts associated with currently available technology. These impacts range from those associated with the biomass production cycle to those associated with the conversion technologies. A checklist of areas of concern emerges:

- $\quad$ Biomass production issues

- Hydrology/soils

- Lack of an integrated land resources and land use data base

- Wildlife habitats

- $\quad$ Species diversity

- Aesthetics of land usage

- The effects of sustained land usage for high-yielding energy crops (sustainability).

- Biomass conversion issues

- $\quad$ Air emissions and impacts

- Water utilization and effluents

- Residue (ash) disposal.

Unlike the biomass production issues, the impacts associated with the combustion systems are already fairly well defined, and environmental regulations are already in place that will dictate the performance level of an electricity production system.

The present day industry is based almost entirely on the conversion of wastes and residues. As a result, the current environmental impacts of biomass conversion processes raise very few questions on the fuel supply side. The biomass supply currently used is composed of material that has already been harvested or used more than once; thus, it is part of the residue recycle system. The resource issues raised relate to the dynamic nature of the composition and source of residue streams with time.

Even though the fuel value of biomass resources on a unit mass basis is hardly changing, the quality is changing, especially with respect to minority components, including ash and trace metals. These changes in the waste/residue streams are necessitating increased investment in particulate and gaseous emissions controls. Even more importantly, the changes will affect ash disposal requirements. Ashes derived from clean wood residue are returned to the forest lands in Scandinavia as a soil amendment, for example, whereas urban wood wastes may have to be disposed of in landfills, depending on the heavy metal content.

A very large increase in the absolute amount of bioenergy used is forecast for the next two decades and this increase will require dedicated fuel supply systems (DFSS). The crops to be grown in DFSS are currently being developed and are either based on short-rotation woody crops (SRWC), such as poplar or eucalyptus, or on herbaceous energy crops (HEC), such as switchgrass. Neither SRWC or HEC require intensive water or fertilizer, and the production systems are designed to minimize the land operations to reduce the likelihood of erosion. Nevertheless, the projected scale of bioenergy 
production systems, 8-16 quads of primary energy, will require plantings on a large proportion of the lands currently set aside to conserve land and constrain uneconomical foodstuff production.

This report was written after surveying the current literature base and taking input from recognized leaders in the biomass-to-energy community. It identifies areas that will require increased research and monitoring to ensure the sustainability of the renewable biomass resource.

\section{Biomass Resources}

Biomass provides us with timber, food, feed, fiber, and energy. The total energy equivalence of grain is about 5 quads; that of wood and paper products is also about 5 quads. The energy component comes from wood wastes, forest thinning residues, agricultural residues, food processing wastes, waste urban wood, and fiber/energy crops. Current use of biomass for energy in the United States is about 3.5 quads per year, including industrial steam production and residential heating. About 0.8 quad is being used to generate electric power. More than $75 \%$ of biomass fuels are logging residues and waste by-products, which would otherwise be disposed of in a landfill or by open field burning.

A recent study by the Institute for Gas Technology (IGT) indicates that with improved forestry operations, additional segregation of the wood portion of municipal solid waste (MSW), and some cultivation of energy crops, 14.6 quads could be available by the year 2000. The U.S. Department of Energy's (DOE) estimates are somewhat lower. DOE predicts that by the year 2030, 9.6 quads could be produced on currently available land using conventional agricultural practices, or 14.8 quads could be produced if ongoing research is effectively utilized. The latter increase in biomass presumes that economically viable biofuels production processes will mature. The National Renewable Energy Laboratory (NREL, formerly the Solar Energy Research Institute [SERI]) sees this increase in biomass production leading to nearly 3 quads of electric power generation, while the market for transportation fuels will grow to nearly 9 quads.

\section{The Economics of Biomass}

To a limited extent, biomass-fueled power generation competes for resources with higher value uses, such as lumber, paper, and firewood. Currently, pulp for paper is priced at more than $\$ 90$ per bone dry ton, and firewood is between $\$ 145$ and $\$ 210$ per cord. About $30 \%$ of wood from a timber cut ends up in chip form, for supplies or use as fuel, bedding, or fiberwood. Thus, most people see biomass fuels production as a complement to the use of wood for other purposes. Since the 1970s, the demand for the resource has justified the costs of in-forest thinning; fuel harvesting is now being practiced in conjunction with silviculture and fire protection. Criteria for retaining cover on the forest floor and procedures to prevent soil erosion or compaction have been set at the local levels.

A decade ago, many supporters of biomass conversion facilities anticipated that agricultural residues would become important biomass fuels; however, because of the cost of collection and the difficulties of burning them, this has not happened. Agricultural residues make up a sizable amount of the resource in California because many plants in the Central Valley have air emissions permits requiring that they use wastes that would be otherwise open-field burned; there is notably better control of particulates at these plants where electrostatic precipitators or baghouses are standard equipment. It has become evident that the physical and chemical characteristics of agricultural residues make them less desirable than wood; they often contain high levels of alkali metals such as potassium and sodium, which tend to form salts that agglomerate on the interior surfaces of boilers. Agricultural residues contain much less sulfur than coal, but sometimes sulfur dioxide emissions control is needed, such as absorption by limestone during combustion in the circulating or bubbling beds of the atmospheric fluidized bed plants. 


\section{Availability of and Alternatives to Land Use}

The American Forestry Association (AFA) estimates that the United States has 483 million acres of productive timberland, 350 million acres of cropland, 116 million acres of marginal cropland or pasture, and 80 million acres of land idled under federal programs. Forty-five million acres of damaged, highly erodible land are currently held within the Conservation Reserve Program, of which one-eighth may be converted to woody cover. (In California only 183,000 acres are in the Conservation Reserve Program and about 185,000 acres in the Acreage Conservation Reserve. However, the resource inventory specialist for the Soil Conservation Service in California estimates that there are between 5 and 10 million acres of the 85 million acres of nonagricultural, nonurban land, which have never been farmed and could be categorized as "good" marginal cropland.) Overall, throughout the United States, 500,000 acres of productive timberland are being diverted into other uses each year. This represents a potential of nearly $400 \mathrm{MW}$ of biomass-fueled power.

Few dispute the importance of "habitat conservation areas" to provide protection to threatened or endangered species and to generally preserve biodiversity, but the current availability of biomass resources in the Northwest is being affected by the uncertainties associated with defining the areas set aside for protection of the northern spotted owl. Rather than find themselves penalized for failing to adhere to what are at best ambiguous regulations, many forest managers and timber owners are postponing harvesting operations and waiting $\cdots$ the hope of forthcoming clarifications. Wildlife habitats are and will continue to be incorporated in the biomass resource development planning. And it is important to note that where damaged or marginal lands are used for biomass fiber/energy crops, habitats will be created as well as preserved.

\section{Water Resource Constraints}

Most of the western United States is arid, and water is of critical concern. Any increase in water demand, as well as alterations in the use of land throughout a watershed, is likely to require changes in water resource management. This does not need to have negative implications, however. Thoughtful development of biomass resources can be a way to improve watershed protection and the integrity of riparian areas.

Steam-turbine power plants use large amounts of high-quality water in their boilers, and as it is boiled off, more must be added. In cooling towers, water generally is recycled several times, but there are large losses through evaporation. The next generation of biomass conversion technologies will also need good-quality water, for while gas turbines do not have boilers, in many instances they use water for cooling to prevent $\mathrm{NO}_{\mathrm{x}}$ formation. Disposal of wastewaters is a further concern, and although some plants discharge some effluents into local sewage systems, "zero-discharge" is becoming the standard.

Relatively little is known about the process of biochemical degradation during the storage of biomass fuels, although NREL has begun studies. Most of the material is volatile, but it is possible that one or more of the breakdown products could be toxic. There must be some monitoring of any substances being leached from stored wastes into the soil and/or groundwater, at least until it is established that no potential problem exists.

\section{Air Emissions}

As mentioned in the discussion of the use of agricultural residues, particulate and $\mathrm{SO}_{2}$ problems are quite readily solved in energy processes. Even though there is very little fuel-bound nitrogen in biomass, any thermal $\mathrm{NO}_{x}$ formed during combustion needs to be mitigated to meet clean air standards. Noncatalytic emissions controls, such as ammonia injection, are increasingly being used. 
Excess ammonia reacting with any chloride present in the fuel has caused some plants to have difficulty meeting a $20 \%$ opacity limit.

Dust (or fugitive emissions) is a major concern at all plants where fuel is stored in the open. Fines must be controlled by wetting the fuel piles. Also, the very fine fly ash must be kept covered and/or wet to keep it from becoming at least as great a dust problem. The ash has value as a soil amendment, but it must be either plowed into the soil immediately or applied in pellet form.

\section{If Biomass Is To Be a Preferred Energy Resource in the 21st Century}

The main requirements for using biomass in a sustainable manner and in environmentally appropriate ways are: (1) intelligent management of all aspects of development, and (2) effective institutional communication and cooperation. Environmental considerations can be handled wisely if good information is compiled and well used and if decisions are made within a collaborative political extent.

Judgments and decisions about environmental impacts must be made in terms of clearly identified and understood ecosystems. Many of the representatives of the individual states participating in DOE's regional biomass energy programs are supporting the development of biomass resource assessments. These assessments are gradually being linked to other state programs, which focus on the management of timber, soils, agriculture, wildlife, water, air, and other energy resources. Geographic information systems, with sophisticated simulation, mapping, and graphics capabilities, are being used with increasing frequency. These systems will be of enormous value if the information is updated regularly and if information in different systems can be related and correlated. These systems offer the best means for monitoring biomass production and conversion, thus providing the information needed to ensure that biomass is developed and utilized in an environmentally sustainable manner. 


\section{Introduction}

This study reviews the environmental implications of continued and increased use of biomass for energy to determine what concerns have been and need to be addressed and to establish some guidelines for developing future resources and technologies.

Although renewable biomass energy is perceived as environmentally desirable compared with fossil fuels, the environmental impact of increased biomass use needs to be identified and recognized. Industries and utilities evaluating the potential to convert biomass to heat, electricity, and transportation fuels must consider whether the resource is reliable and abundant, and whether biomass production and conversion is environmentally preferred (see Figure 1).

A broad range of studies and events in the United States were reviewed to assess the inventory of forest, agricultural, and urban biomass fuels; characterize biomass fuel types, their occurrence, and their suitability; describe regulatory and environmental effects on the availability and use of biomass for energy; and identify areas for further study. The following sections address resource, environmental, and policy needs. Several specific actions are recommended for utilities, nonutility power generators, and public agencies. 


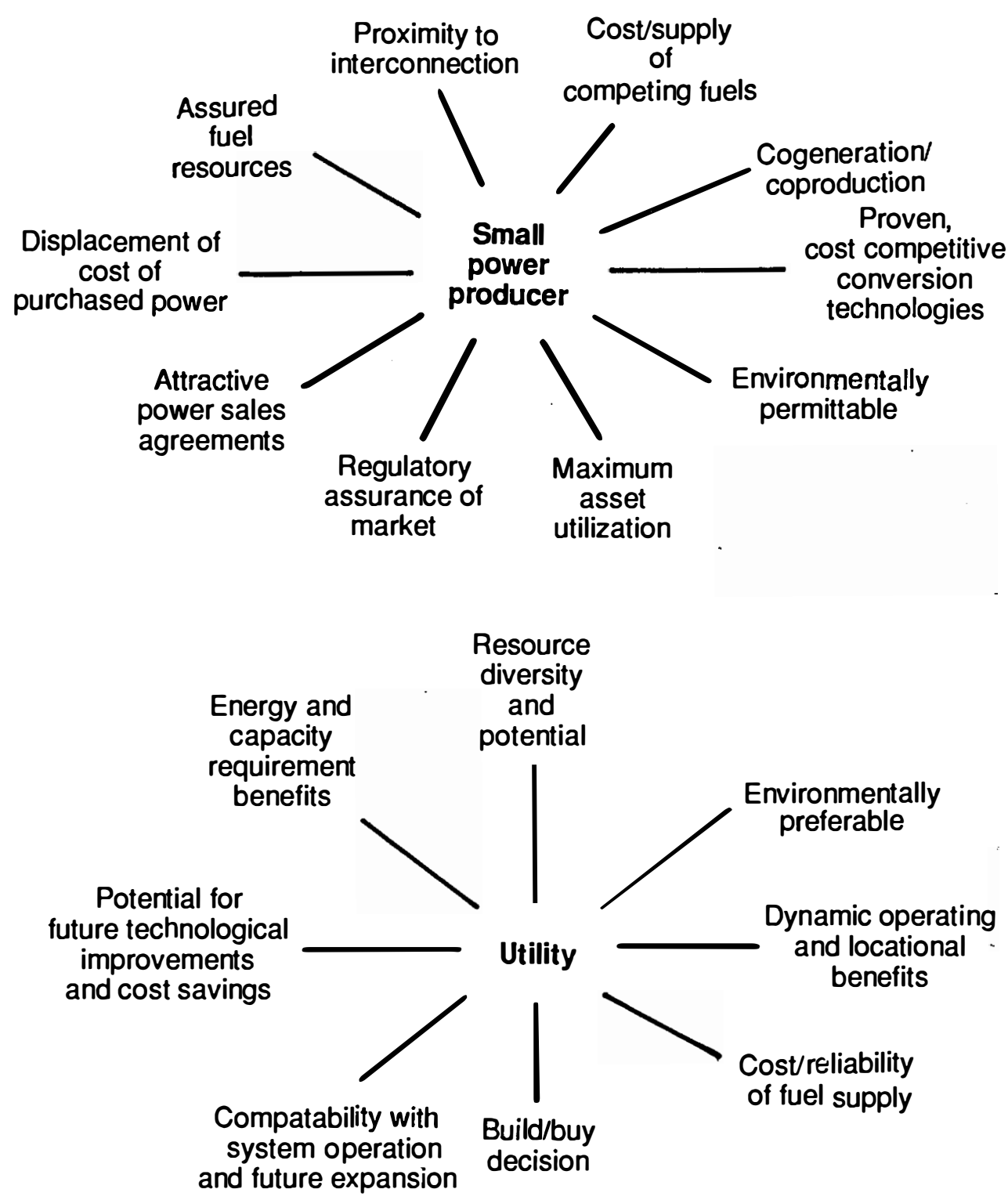

Figure 1. Factors influencing selection of a resource/technology Source: Paclflc Gas and Electrlc Company, San Ramon, CA, 1990 


\section{Biomass Resources and Energy Demand}

Biomass resources include forest resources, agricultural crops and residues, and herbaceous and woody energy crops. The 3.5 quads of biomass energy used each year come from many sources, including wood, agricultural and forestry residues, woody and herbaceous crops, aquatic plants, the organic fraction of municipal wastes, and landfill gas. By one estimate, about 14.6 quads, or about five times the current use, could be recovered by the year 2000 (see Figure 2) (Klass 1990).

The most important environmental benefit of biomass energy is the use of wastes from forest harvesting, forest industries, urban wastes, and agricultural production. More than $75 \%$ of biomass energy is now generated from logging residues and waste by-products from the conversion of waste wood to paper, chemicals, and solid wood products. The conversion of wood and pulping liquors to steam and power accounted for two-thirds of wood energy use in 1987, or about 1.9 quads. Residential combustion, largely from logging residues, accounted for another $30 \%$ of wood energy use, or about 0.9 quad (see Figure 3) (Klass 1990).

Forest residues, crops, crop residues, and even manures have been tried as fuel because demand has absorbed available residues from forest industries. Biomass residues from forestry and intensive cultivation promise to be the principal future resources for most areas.

About 3 quads of energy are potentially recoverable from municipal solid waste (MSW). By-products of food, fiber, and energy production combine with imported resources to produce an annual stream of MSW equal to one-half ton per person per year. MSW proves to be a complex fuel, but in largescale plants it is becoming an important source of electrical power. Only the wood portion of MSW is considered here; equal to about $15 \%$ of the incoming solid waste, it is now separated in many locations for conversion to electrical energy (Combs 1990; Grasso and Atkins 1991; Miles and Miles 1991; Morris 1991).

By the year 2000, new energy from crops, intensive forestry, and aquatic plants are estimated to contribute 1.8 quads to the biomass energy supply, equal to $50 \%$ of current use, as shown in Table 1 (Klass 1990). The potential impact of fuel use on the environment increases as fuel sources expand to include forest, agricultural and urban residues, and special crops.

\section{Energy Consumption and Future Biofuel Demand}

Biomass contributes about 3.5 quads to U.S. energy consumption, or about $4 \%$ of the 80 quads consumed from all sources. Figure 4 shows that a small change in petroleum or coal consumption would equal a large change in biofuel production. An increase in biofuel production to 14.6 quads represents about $80 \%$ of the current consumption of coal at 18 quads (Klass 1990; U.S. Congress 1990; U.S. DOE 1991).

DOE estimates that energy from biomass can increase while food and fiber production is maintained. DOE's goals for the year 2030, depicted in Figure 5, show food grains and wood products represented by their energy equivalents. Biomass production and conversion would increase to 14.8 quads through intensified research, development, and demonstration when economics favor biofuel use. Three-fourths of the new production would derive from ethanol, methanol, and reformulated gasolines produced from woody, herbaceous, and grain crops on agricultural lands. (Solar Energy Research Institute 1990; Lee et al. 1990; Chum and Overend 1991; Davis 1991; Electric Power Research Institute 1990; Lynd et al. 1991). 


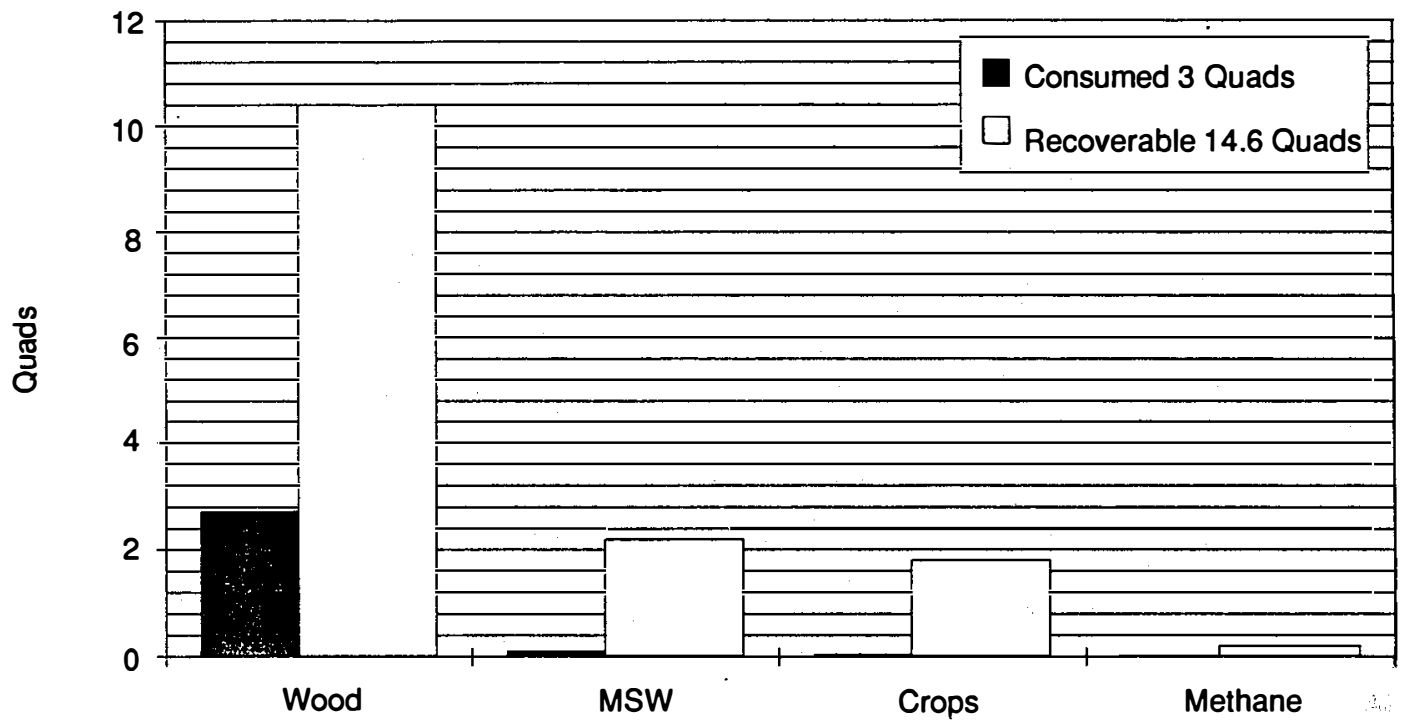

Figure 2. Potential U.S. biofuel resources (2000) Source: Klass 1990

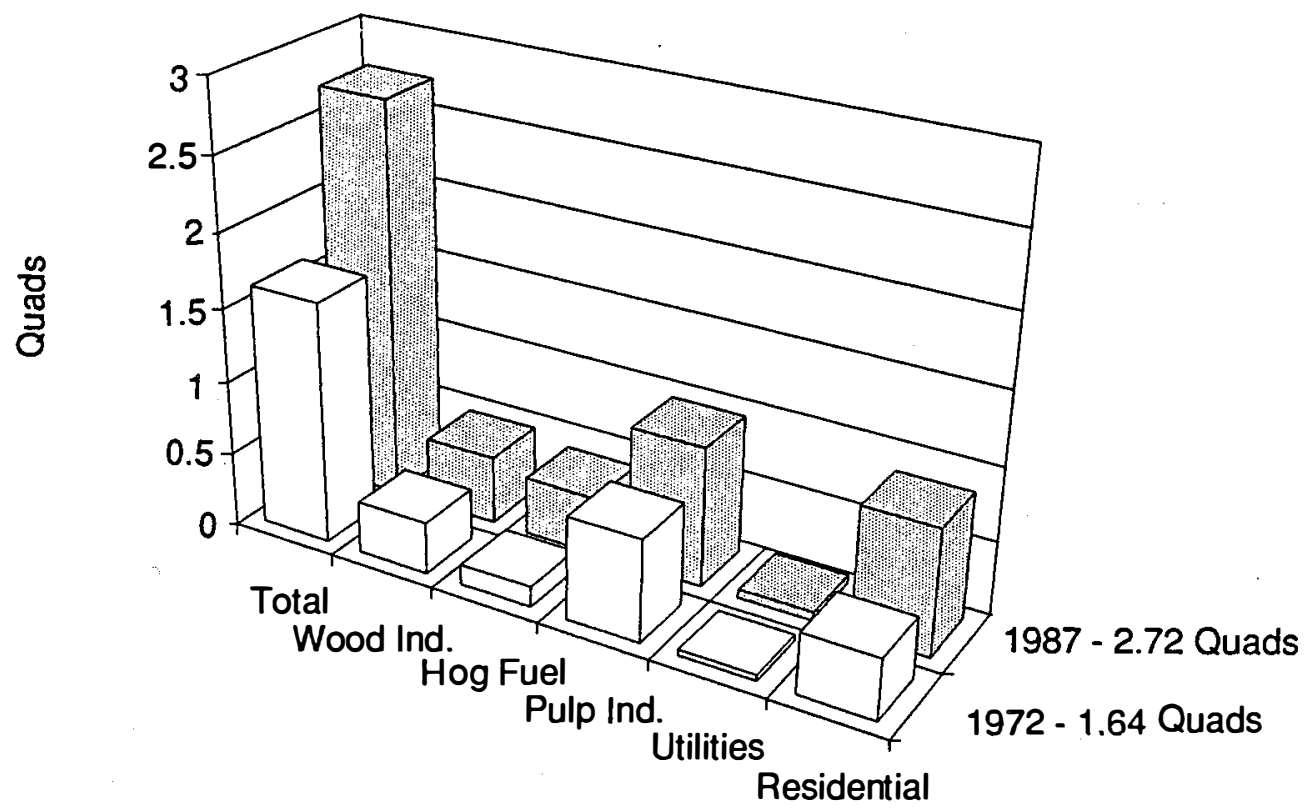

Figure 3. Wood energy use (1972, 1987) Source: Klass 1990 


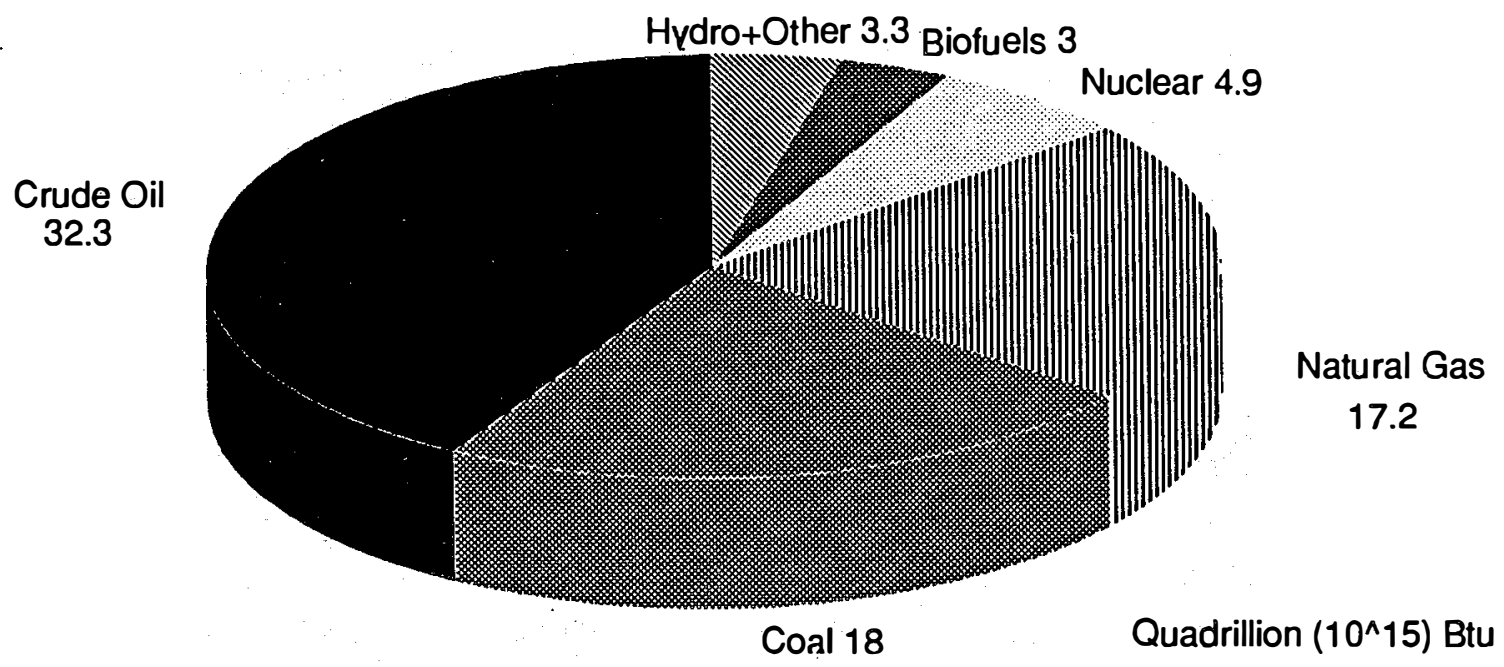

Figure 4. Sources of U.S. energy (1987)

Sources: Klass 1990; U.S. DOE 1991

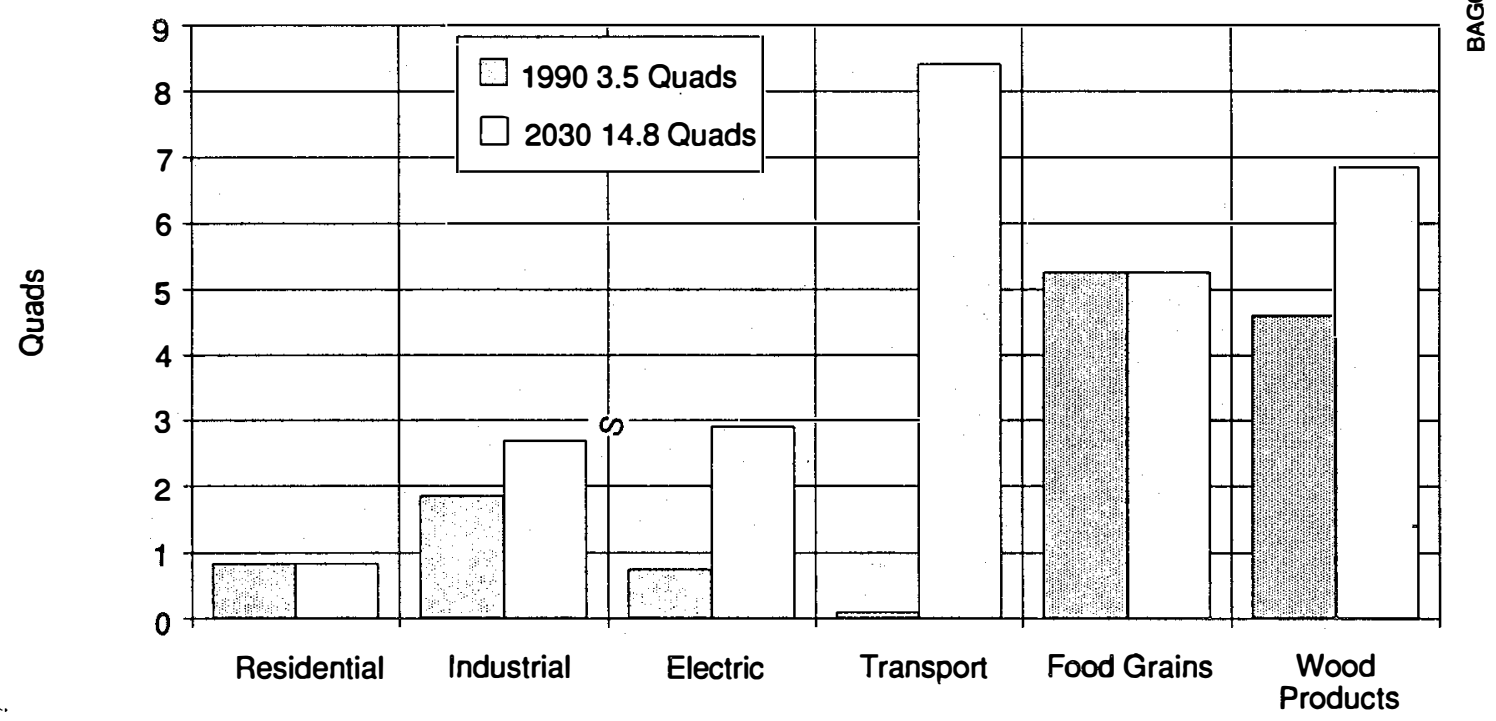

Figure 5. Current biomass consumption and U.S. DOE goals for 2030 Source: Chum and Overend 1991 
Table 1. Recoverable Energy From Biofuels

Source: Klass 1990

\begin{tabular}{lc}
\hline Fuel Source & Quads/Year \\
\hline Wood & 10.4 \\
Municipal Solid Waste & 1.8 \\
Agricultural Residues & 1.0 \\
Aquatic Biomass & 0.8 \\
Industrial Residues & 0.2 \\
Sewage Methane & 0.1 \\
Manure Methane & 0.05 \\
Miscellaneous & $\underline{0.05}$ \\
Total & 14.6 \\
\hline
\end{tabular}

Although the use of biofuels for power production has concentrated in wood-producing areas, as shown in Figure 6, future demand is expected in the South and Midwest (see Figure 7). Improved efficiencies are also expected in biofuel power generation and the conversion of industrial fuels to steam and power. Estimates of regional demand for electricity and natural gas show higher future demand in the South and Midwest, where biomass is low in cost and more accessible, and where future production is expected to occur (see Figure 7) (Solar Energy Research Institute 1990).

The projects recognize that small increases in energy are possible through traditional forestry and residues, but major advances must be made through intensive biomass cultivation and intensive forest management.

\section{Current Demand for Biofuels}

Residential heating, process steam, cogeneration, and power production now consume most of the industrial biomass wastes. Biomass energy conversion for power generation is unevenly distributed in the United States. It has been concentrated where sawmills, pulp mills, and board manufacturers cogenerate power from wood residues, but production is shifting to locations where more, and inexpensive, biomass is available relative to power demand.

Fuel prices reflect demand for biomass resources. They have been stable in areas like the Northeast, Northwest, and Southeast, where a significant infrastructure has been developed compared with biomass energy demand. Prices are volatile where supply struggles to catch up with a growth in consumption, as in California (Morris 1991; Turnbull 1991). Demand is expected to shift as timber harvests are reduced in the West and fiber and fuel production continue to increase in the South.

Biofuels now move between regions. High prices in California have drawn wood wastes 800 miles by ocean barge from the Northwest to supplement local fuel supplies for the current $750 \mathrm{MW}$ of biomass-fueled electrical capacity. 


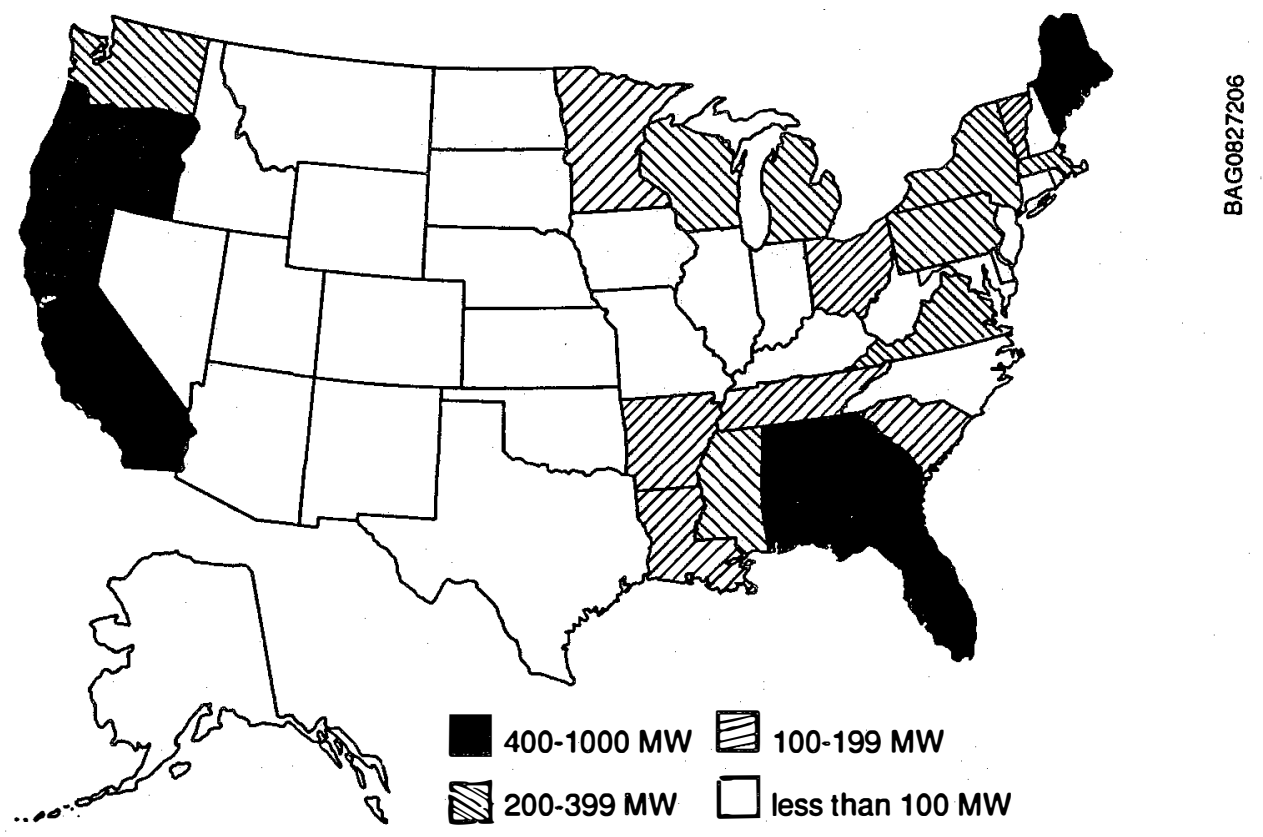

Figure 6. Biomass electricity generation by state (1989)

Source: Solar Energy Research Instltute 1990

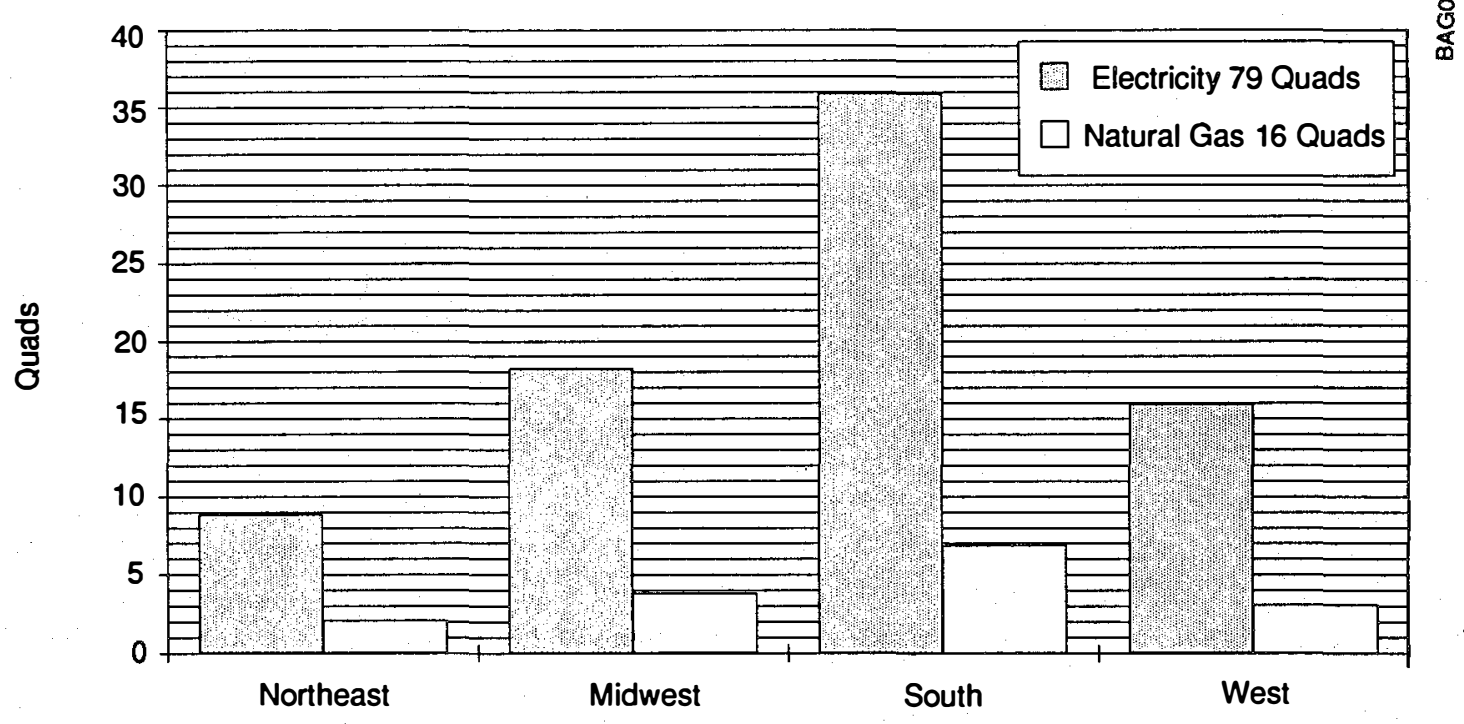

Figure 7. Demand for electricity and natural gas in quads (2030) Source: Solar Energy Research Institute 1990 
Demand for solid wood and paper inflates the price of wood for energy. At $\$ 110$ per ton, bone dry (BDT), the value of wood for fiber is more than three times the value of wood for fuel. Also, methods to recover wood fiber for paper have changed the market definition of "residues" so that some mill waste once sold for fuel is now used for paper and panel products. Hence, an increase in demand for wood or paper removes supplies of "fuel" from the energy pool. It is the value of biomass for fiber, not fuel, that has stimulated private investment in short-rotation biomass plantations in the United States and New Zealand. Energy production will remain a complement to fiber production unless low-cost techniques are developed to grow biomass for fuel (Sims et al. 1991).

Forest residues or "biomass" harvesting have been important fuel sources during periods of scarcity and have been regarded as future reserves of biofuels. The Northeast and Southeast were the first areas to integrate fuel harvesting with silviculture and timber management to supplement limited supplies of mill residues. However, costs of forest residues have increased in most areas, so that they are not as readily available now as they once were. Separate entry for fuel harvesting is expensive, and often avoided, because the harvest season is usually short and the overhead costs to build roads and comply with special permits are high compared with the residue value as fuel. Environmental concerns are important costs and risks for fuel harvesting (Kennel 1984; Associates in Rural Development 1986).

Demand for urban wood residues has increased sharply, but supplies are low compared with total demand. Urban wood processing systems have appeared in the Southwest and Northeast. They are expected to increase as permits to burn urban wood are made available. Urban wood now supplies about 15\% of power plant fuels in California (Combs 1990; Grasso and Atkins 1991; Morris 1991; Miles and Miles 1991; Turnbull 1991).

Demand for agricultural residues has diminished. Interest in the use of hulls, stalks, and straw as fuel dropped sharply with energy prices in about 1984. At approximately \$40/BDT, most crop residues are expensive fuels. Adequate short-term supplies of natural gas have also diminished interest in crop residues as farm fuels. And technologies to convert crop residues to liquid fuels, such as pyrolysis or enzymatic hydrolysis, are still too costly. Consequently, there is more demand for land to produce fiber crops than there is for residues from existing crops (Conklin et al. 1991; Morris 1991).

Estimates of biomass resources and accessibility and the creation of new biomass resources must be continually evaluated. The resource is influenced by the changes in environmental, recreational, and urban priorities that are reflected in land use.

\section{Land Use}

Land use impacts on biomass resources are often not taken into account in resource accounting. Land potentially available to grow biomass for energy encompasses more than 483 million acres of productive timberland, 350 million acres of cropland, 80 million acres of cropland idled under federal programs, and 116 million acres of privately owned marginal crop and pasture land (American Forestry Association 1990; Council for Agricultural Science and Technology 1990; Sampson 1991).

Economic priorities and environmental values, such as outdoor recreation and wilderness; wildlife habitats; forestry; agriculture; and air, land, and water quality, cause changes in land use. In the United States, it is estimated that about $0.1 \%$ of productive timberland is diverted to other uses each year (American Forestry Association 1990). This equals about one-half million acres or approximately $384 \mathrm{MW}$ of biomass power potential. In the last century, much of this land was converted to cropland, but in this century it has been converted to urban uses. 
Each year between 1967 and 1975 about 2.08 million acres of cropland, with a biomass electrical energy potential of about $1500 \mathrm{MW}$, was converted to urban, residential, and transportation uses. These lands are permanently removed from the resource base.

Wetland legislation and its interpretation will also determine the amount of land available for growing biomass for energy, because woody crops require low-cost land and abundant water. The conversion of $80 \%$ of the nation's wetlands to farmlands and estimated losses of 290,000 acres per year have brought forest wetlands into focus as an environmental concern. Natural forest wetlands are important habitats that some interests want to restore or preserve without energy or agricultural production.

Land set aside under the Conservation Reserve Program (CRP) is often considered for biomass production; however, the goal of the program is to control soil erosion, not reforestation. Conservation reserve areas are set aside for soil conservation under plans adopted through the local soil and water conservation districts. Not all lands removed from agriculture to acreage reduction programs or soil conservation programs are candidates for biomass fuel or fiber production. And CRP acres can only total $25 \%$ of the total cropland in a local area (Zinn 1989).

CRP agreements are voluntary programs in which farmers establish trees or grass on highly erodible land in exchange for an annual rent or subsidy. Land use is short term by definition because contracts are limited to 10 years. Other incentives may be necessary for participating acres to stay in trees after the rental payments have ended. In fact, only one-eighth of the projected 45 million CRP acres are destined for woody cover, and to date little more than 2 million acres have gone into trees. Analysts point out that eligible acres are low in value and productivity. In addition, these acres are primarily between the Rockies and the Mississippi, in areas suffering water shortages. Legislation will have to change before those acres find their way into woody crop production (Zinn 1989; Council for Agricultural Science and Technology 1990).

Recently enacted environmental laws and other public policy decisions have decreased the available supply of biomass for energy, when land has been removed from commercial production until environmental issues are clarified or legally resolved. Examples are the creation of "habitat conservation areas" for protection of the northern spotted owl, which reduced the allowable timber production, and reserves for the rehabilitation of wetlands. Although these laws could serve to enhance both the biodiversity and long-term sustainable production of biomass, in the short term they remove land from biomass production, decreasing current inventories (Wilkinson and Anderson 1987; Greber et al. 1990).

By DOE estimates, 69 million acres of cropland not currently being used is capable of supporting biofuel production as shown in Figure 8. An estimated 9.6 quads of energy crops could be produced on the land by applying current research (see Figure 9). By the year 2030, under accelerated research, development, and demonstration programs, 192 million acres of current and new cropland could produce an additional 26 quads. The greatest energy potential lies in the Midwest and the South, where cropland is available and use is low compared with demand. The DOE energy goal of 14.8 quads (Figure 5) appears to fall between their estimates for current and future land and management. Land use issues will be central to any future large-scale biomass production (Turhollow et al. 1985; Solar Energy Research Institute 1990).

\section{Water Resources}

Water resources are essential for producing biomass. A review of environmental impacts of renewable energy technologies in 1981 pointed to water problems in 21 river basins as potential limits to 


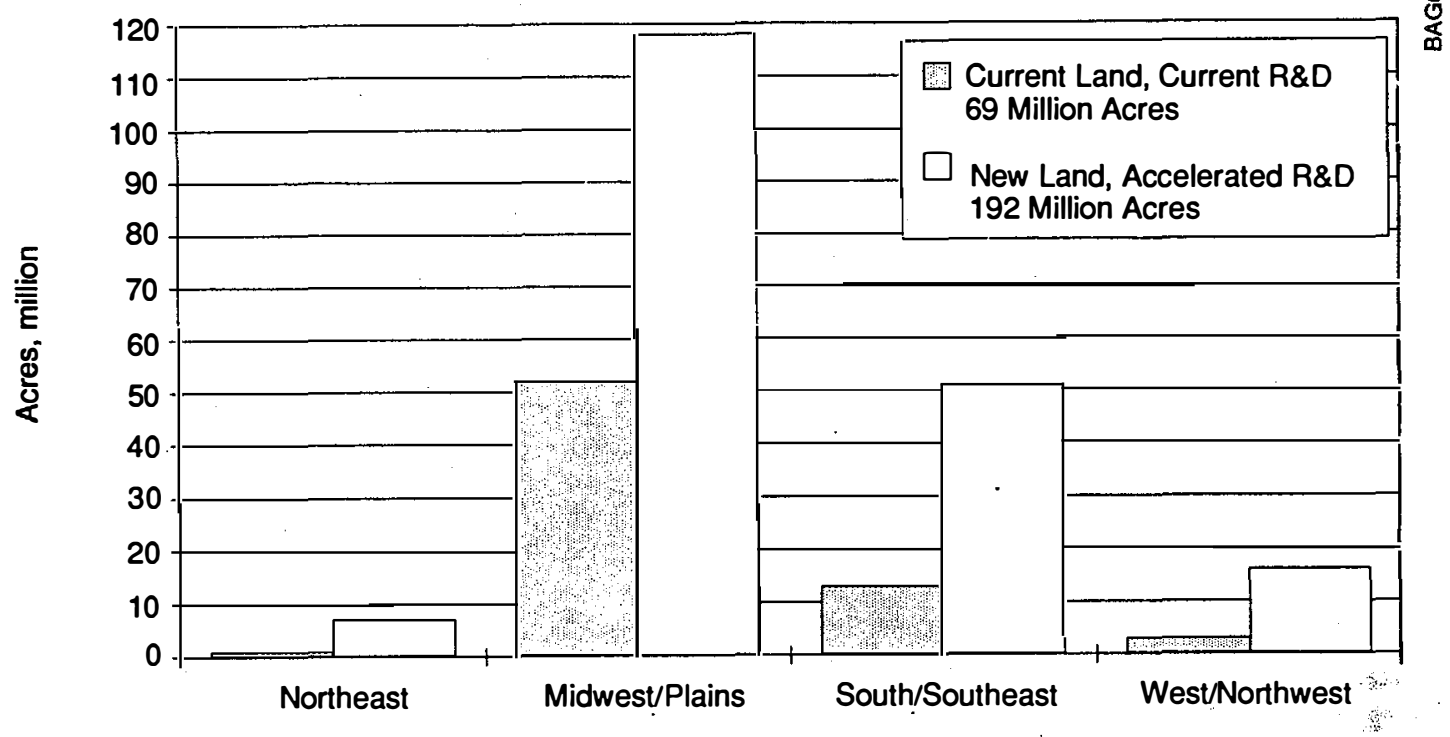

Figure 8. Cropland available for biomass energy production (2030) Source: Solar Energy Research Institute 1990

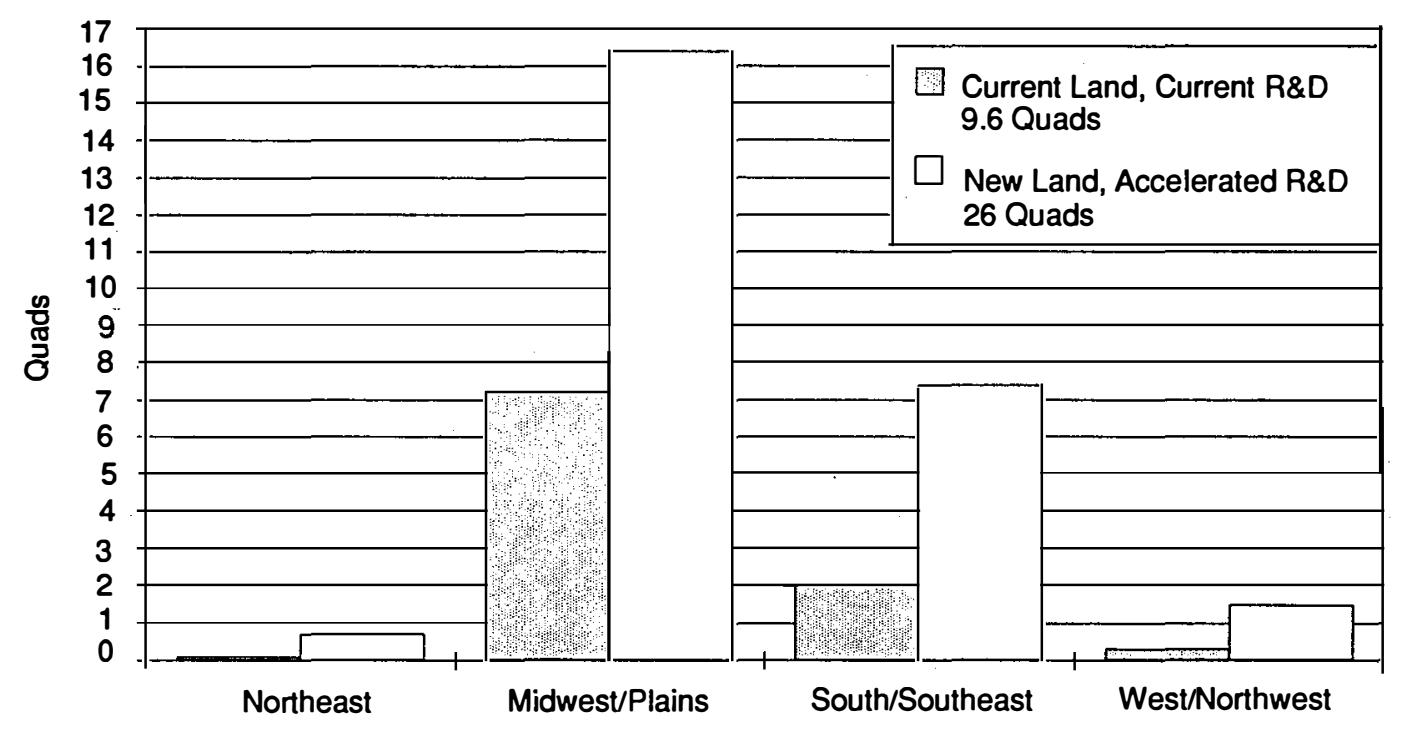

Figure 9. Primary energy potentially available from cropland in quads (2030) Source: Solar Energy Research Institute 1990 
biomass production. Current and future water supply deficiencies in the Midwest were highlighted (Braunstein et al. 1981).

Since that time, water use for irrigation and thermoelectric utilities has stabilized through improved practices and reduction in irrigated cropland; however, public and rural water use continued to increase with increased per capita use (Council on Environmental Quality 1989). Thermoelectric demand may actually increase as more water is used to control $\mathrm{NO}_{\mathbf{x}}$ from natural gas fired turbines in the next decade (Turnbull 1991).

In 1985 irrigation withdrawals accounted for $34 \%$ of total water consumption and $80 \%$ of all consumptive water use in the United States. The Council on the Environment indicates that many of the concerns about water shortages arise because of uneven distribution of water in relation to regional and seasonal distribution of water demands. Concerns also arise because of increasing difficulties in distribution. In some instances, changes in engineering, management, or institutional procedures and increased conservation may improve the situation. An increase in water demand may have to be accompanied by changes in management of the water resources (Council on Environmental Quality 1989).

It appears that water resource planning and development will have to accompany large-scale biomass resource development. Although biomass resources are considered in water basin planning and land use, more information will be necessary for water limitations to biomass production. At least for short-rotation woody crops, arid lands where biomass production would create water shortages have been avoided.

\section{Resource Information}

Estimates of biomass resources available for conversion to energy have been improved since the 1970s. Some states and regions appear to have established reliable sources of information on waste streams, but others still need to develop systems to identify biomass resources and locate future resources (Meimban and Govet 1989; Hinman et al. 1990; Howard 1990; Oregon Department of Energy 1990; Peak Environmental Management 1991).

It is difficult to find information with common geographical boundaries to estimate the environmental impacts of biomass. Biomass resource managers and energy developers understand that information about biomass production, harvesting, and use is usually handled by different people in different agencies who have little interest in energy, but are concerned about the competing uses for biomass and for the forest and cropland on which it is produced.

Increased biomass use will require improvements to the supply infracture; the production, harvesting, and transport of biomass fuels; and management of the resource. Fuel inventories should be managed to provide opportunities to improve wildlife habitat, water quality, and site productivity. It is clear that information that is comparable and expressed in common terms would be useful for more efficient use of biomass and for environmental protection.

More detailed scientific studies of biomass resources are needed. The resource has been clearly overestimated in some cases, especially when aggregated to regional and national levels. Production and residue coefficients that were used in the past need to be evaluated against actual harvesting and collection experience (Howard 1990).

Cost data have been generated in several regional studies. The costs of harvesting and collection of specific forest and agricultural residues determine whether they are removed for energy conversion or managed in other ways. These costs should be included along with the resource information to 
be used in logistical models that could assist in future plant siting and environmental assessments (Jenkins 1983; Briedeman and Fox 1990).

The impact of potential additions or withdrawals from timber, pulp, or fuel production to other uses should also be assessed. For example, the specific potential impacts of resources that could be grown on agricultural set-aside programs need to be determined. Rules for set-aside programs need to be evaluated to determine whether these programs can "create" biomass resources that could have a subsequent environmental impact. Set-aside programs are usually managed by soil and water conservation departments, not energy specialists. In some cases, the impact on overall energy resources is marginal, from a state perspective. A significant withdrawal, such as that resulting from wildlife habitat and wetland issues, usually affects the timber harvest in general.

Information systems should be developed that can be used for energy, economic, and environmental purposes. Biomass data become outdated as patterns of land and resource use change with demands for energy, food, or fiber products. Detailed estimates of timber resources must be combined with similar analyses of urban and agricultural residues. Production, harvesting, and conversion information should then be related to conditions of air, land, and water quality (U.S. Congress 1990).

Processes should be developed to keep resource assessments updated. Dynamic biomass resource information systems could provide information both for environmental and industrial planning. Data could be added or revised according to changes in forest ownership, land use, and cropping patterns. This would provide dynamic support for energy producers and could be used for logistic models to site facilities (Jenkins 1983).

The U.S. Department of Agriculture (USDA) Forest Service and some state agencies are mapping resource data for timber, wildlife, land use, and water with computerized geographic information systems (GIS). Several states are integrating resource information into natural resources decision support systems using GIS techniques. One water basin study area is developing a system for decision making and to facilitate comprehensive environmental policy and planning. Information has been organized into 21 data layers, including soils, wetlands, land use, timberlands, threatened and endangered species, water quality, and water use. A resource evaluation process has been developed to integrate the information for policymakers (Hale et al. 1991). All state energy departments should cooperate in the development of these systems, even those that may not yet have budgets to develop such information.

\section{DOE Regional Programs}

The DOE regional biomass energy programs are useful forums to record biomass resource use and to obtain initial estimates of environmental impacts at the state level. State representatives of these programs are important links between energy and the environment because their responsibilities often connect them with management of forestry, agriculture, wildlife, and water and energy resources. They are often the best authorities for energy demand, other biomass demand, and changes in the use of land and biomass resources (see Figure 10).

Through these programs several states have assessed the availability and production of biomass resources and identified potential sites for biomass conversion. Regional programs have supported specific studies of resource availability such as the logging residues in the Northwest, lignocellulosic raw materials in the western region, the alcohol fuels in the southern states of the Tennessee Valley 


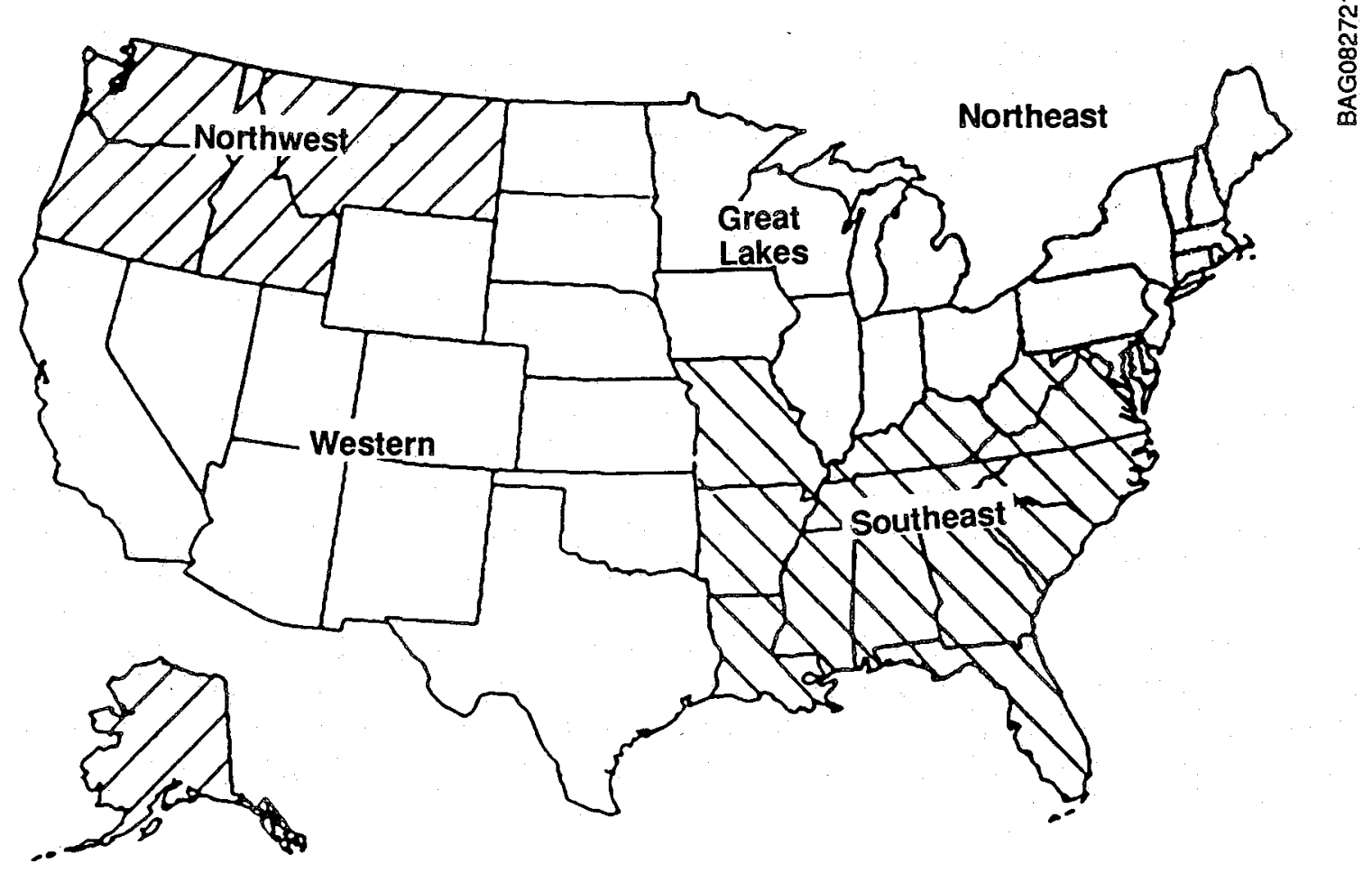

Figure 10. DOE regional biomass programs Source: Wood 1989

Authority, and the fuels of the Northeast. As shown in Table 2, some states have also proposed strategies to use biomass resources to mitigate global climate change (Meimban and Govet 1989; Sifford 1989; Wood 1989; Hinman et al. 1990; Howard 1990; Oregon Department of Energy 1990).

The potential of an important new resource, urban wood wastes, is being characterized through the regional programs, in conjunction with the New York State Energy Research and Development Authority (NYSERDA), Environment Canada, and others. This and many other regional projects are considering the environmental impacts of biomass harvesting, production, and conversion to energy (Grasso and Atkins 1991; Hinman et al. 1990; Howard 1990; Meimban and Govet 1989; Sifford 1989; Wood 1989; State of Connecticut 1990). 
Table 2. Environmental Topics in DOE Regional Program Studies

Sources: Bonneville Power Adminlstration Paclflc Northwest and Alaska Regional Bloenergy Program (PNW) 1989; Councll of Northeastern Governors (CONEG) 1989.

Biomass Production and Harvesting

Soils

Effect of felling and yarding on soil properties (PNW).

Effects of residue removal on nitrogen loss (PNW).

Effect of residue removal on site productivity (PNW).

Air Quality

Effect of residue removal on emissions (PNW).

Effect of nonburning removal systems on productivity (PNW).

Impact of residential wood combustion (PNW).

Alternate systems of residue disposal (PNW).

Regional pollution reduction through increased recovery for energy (PNW).

General Environmental

Environmental impacts of intensive pine recovery for energy (PNW).

Economic and environmental aspects of biomass energy (PNW).

\section{Biomass Conversion Technologies}

Solid Waste Disposal

Wood ash disposal and recycling (CONEG).

Energy implications of waste management systems (CONEG).

Air Quality

Impact of residential wood combustion (PNW).

Particulate emission from residential wood combustion (CONEG).

Gasifier emissions testing (PNW).

Air emission regulations for small to moderate size wood-fired boilers (CONEG).

Stack emission standards for industrial wood-fired boilers (CONEG). 


\section{Biomass Fuels: Their Occurrence and Suitability}

\section{Wood Residues}

The U.S. fuel and fiber resources are changing. As the once abundant mill residues from the wood products industry are used up, and as pulp mills and board plants become more efficient at using waste wood for fiber products, wood energy consumers get lower quality fuels at higher prices.

Industry has had to modify plants and equipment to handle different fuels, while meeting increasingly restrictive environmental standards. Waste wood fuels are being hauled longer distances as plant operators look farther afield for fuel. A survey in the Northeast found that most plants haul fuel farther than the presumed 60- to 70-mile radius. The extreme is cited above, where some West Coast mill residues are barged 800 miles to California. And as quality declines, more trips are made to the landfill with larger quantities of ash, increasing costs (State of Connecticut 1990; Folk and Campbell 1991; Morris 1991; Turnbull 1991).

Even with degraded fuel quality, wood residues are the most desired form of biomass energy. Prices and supply of wood residues are usually stable, and wood burns well in existing and new equipment for steam and power generation. The principal challenge for combustion systems has been to accommodate large quantities of fines and bark in the fuel because efficient screening systems now remove larger particles for the paper and board industries. Fines suspend easily in furnace gases to create operating and emission problems, including hot spots, slagging, and high carbon monoxide emissions. These problems are usually corrected in the design or modification of the fuel stoking and furnace systems. As combustion systems become more efficient, e.g., circulating fluidized beds, intrinsic fuel chemistry becomes important. Problems of slagging appear in fuels that do not otherwise cause problems in traditional stokers (Bushnell et al. 1989; Wilhelm and Simbeck 1990).

Forest residues and silvicultural thinnings have now become reliable sources of fuel. In several areas of the United States, wood energy users have become involved in procuring wood from thinnings and silvicultural activities. Chippers and mills have been designed especially for forest residues. When fuel harvesting is integrated with fiber harvesting, the cost of fuel is kept to a minimum. Between $25 \%$ and $35 \%$ of small trees are suitable only for fuel chips.

To preserve fuel supply, utilities are beginning to participate in forest management to the same degree as do forest industries. Burlington Electric, the Vermont utility handling the 50-MW MacNeil Station, has found that field foresters have helped to maintain the productivity of supply and assure stable fuel prices. Vermont has specifically developed a policy on silvicultural practices to follow in order to assure improved forest vitality when fuel is harvested for wood-fired power plants (State of Vermont 1981). S.D. Warren at Westerbrook, Maine, also uses forestry advisors for fuel harvesting.

Shasta-Wheelabrator in California has had similar experiences using forest thinnings to augment fuel supplies. Field foresters ensure that harvesting is carried out according to acceptable forest practices, including environmental impacts. Harvesting is coordinated by a coalition that includes the U.S. Forest Service Area Forester (Carlson 1990; Turnbull 1991).

Dry wood residues are being increasingly converted to wood fuel pellets for use in residential heating appliances (pellet stoves). In some states, air quality regulations have created a demand for pelletwood in stoves. The dry, pelletized wood has lower emissions than green wood. Now more than 30 models of pellet stoves have been tested in those states requiring certification. National wood pellet consumption has grown to 250,000 tons per year (Fiber Fuels Institute 1991). 
In the production of wood pellets, some of the air quality emissions are transferred from the households, which are disperse sources, each burning a few tons per year, to an industrial fuel dryer that processes several tons per hour. There, volatile organic carbons and other products of incomplete combustion are removed in wet scrubbers and wet electrostatic precipitators.

\section{Urban Wood and Mixed Wastepaper}

Wood residues and mixed wastepaper from MSW are suitable fuels for biomass energy. The definition of "municipal solid waste" has changed since the Environmental Protection Agency (EPA) decided on a strategy of waste reduction, reuse, recycling, and thermal conversion. Under the new hierarchy, most woody materials are diverted to composting, and there is less public support for landfill disposal and waste-to-energy plants.

Several large-scale MSW plants are being built, but their designs now include preprocessing, where materials recovery facilities (MRF) separate recyclable components to prepare refuse-derived fuel (RDF) for combustion. Recycling does not preclude burning wastes, because there is always an organic fraction that cannot be recovered. The new facilities are efficient at diverting or directing fiber and fuel products to appropriate uses (Hohman 1990).

As evidence of the pressure on biofuel supply, urban wood wastes, composed of landscape trimmings, building demolition, and commercial and industrial wood wastes, have become important power plant fuels in California, where fuel buyers prefer these wastes to abundant but more chemically challenging agricultural residues. A typical power plant may buy fuel from 30 or more different sources, sometimes channeled through a single broker. Some fuels must be further processed at the plant to remove contaminants that cause problems or create excessive air pollution (Miles and Miles 1991; Grasso and Atkins 1991).

Urban wood waste is characterized by high levels of dirt, dust, and fines, along with large quantities of nails. Emissions or ash disposal problems caused by sulfur, lead, or mercury are rare. In one case, burning the demolition from earthquake-damaged buildings increased acid gas emissions and created "toxic" ash from the electrostatic precipitator, which required disposal in a special landfill. Evaluating the movement, disposal, and impact of these wastes requires coordination with solid waste management agencies and fuel buyers (Miles and Miles 1991; Grasso and Atkins 1991).

The increase in recycling led to the appearance of mixed wastepaper, which has been evaluated as an energy feedstock but is not yet used in large quantities (Lyons and Kerstetter 1990). Criteria to certify urban wood wastes and mixed wastepaper as suitable fuels would alleviate some pressure on solid waste disposal while providing new sources of fuel. The cooperative project under way by NYSERDA and others is expected to provide standards and criteria to use these fuels without adverse environmental impacts (Environmental Risk Limited 1991).

\section{Agricultural Residues}

Agricultural residues are expected to contribute about $1 \%$ of total recoverable biomass energy. During periods of high energy prices, crop residues were used extensively as farm fuels in grain drying and space heating applications, especially in the Midwest. Burners were developed for stalks, straws, and cobs to provide low-efficiency, low-quality heat for drying and space heating. Air emissions were generally high but applications were usually in areas that did not require strict emissions limits (Pisarik 1987; Miles 1988). 
Energy conversion systems for certain crop residues such as rice hulls have been developed to a satisfactory level of industrial use. Rice hulls are converted to power at Lake Charles, Louisiana, and Williams, California (Goss and Miles 1989; Shaddock 1990).

The amount of agricultural residues that is removed for energy must be balanced with the need for soil amendment and erosion control. Most estimates of crop residues have been made from coefficients for straws and stalks developed from harvesting for feed uses. Appropriate methods of stubble management have been a focus of dryland agriculture for many years, and retaining residues for erosion control is a priority for soil conservation and rangeland management (Jenkins 1983; Nelson and Schrock 1991).

Some productivity studies have developed guidelines to determine how much residue can be removed from cropland without causing an imbalance in soil fertility. These guidelines were used in "Residu," a management system for residue removal that was developed for the Great Lakes region. It used soil characteristics to establish residue potential for specific crops according to soil fertility and erosion potential. Guidelines for cereal crops are also being developed in Kansas under the regional energy program (Pisarik 1987; Nelson and Schrock 1991).

Air quality legislation in California provides incentives for power plants to burn field crop residues to offset emissions from open field burning. Particulate emissions per ton of residues are less from a boiler than from open burning. Offset strategies have succeeded in reducing open burning, but some fuels have not always been converted to power because of operational problems. Crop residues such as fruit pits, nut hulls, and straw have not been acceptable fuels for power plants when they exceed $15 \%$ to $25 \%$ of the fuel feed because of slagging in the furnace (Turnbull 1991).

Emissions control equipment has made it possible to comply with air board regulations when burning crop residues. There are reports that chlorine from straw combines with ammonia used to reduce $\mathrm{NO}_{x}$ emissions to form a visible plume. These plumes have been found to be difficult to capture in electrostatic precipitators at power plants, so some plants have had difficulty meeting a $20 \%$ opacity standard.

The physical and chemical properties of agricultural residues make them undesirable for combustion, even when burned in combination with wood wastes. Crop residues and sewage sludge often contain high levels of sulfur and alkali metals, which cause corrosion and deposits in boilers and heat exchangers. The piping and refractory of fluidized bed combustors that can otherwise burn many fuels efficiently become agglomerated with ash when burning crop residues. These problems are also common in Europe, where large quantities of crop residues are burned. Technological solutions are still required if large quantities of crop residues are to be converted to energy (Conklin et al. 1991; Ravn-Jensen 1991).

Dust and fire exposure are the typical fuel handling problems associated with crop residues. These operational problems have limited the total amount of crop residues fired. Energy conversion is a suitable means of disposing of crop residues, when they can be co-fired with other fuels. However, urban wood, forest, and imported mill residues have been substituted in power plants in which agricultural residues were planned to be used as a principal fuel. These operational problems increase the pressure on silviculture and energy crops to meet biomass energy demand.

\section{Energy Crops}

After some early attempts failed to establish woody energy crops, several organizations began to develop fiber and fuel plantations. Efforts during the past decade to produce biomass for energy by the short-rotation intensive culture (SRIC) of woody and herbaceous crops have raised questions 
about the potential environmental impacts on soil compaction, wind and water erosion, and nutrient loss. These questions provided the main impetus for this paper (Wright 1989, 1990; Solar Energy Research Institute 1986, 1990).

Since 1974 more than 20 hardwood plantations have been engaged in SRIC, encompassing more than 20,000 acres (Wright 1989). In the private sector, Simpson Timber has been encouraged by the results of its eucalyptus plantations in California. Simpson has initiated an evaluation of irrigation and fertilization methods, which will be carried out by Humboldt State University. James River Corporation has begun to harvest its hybrid poplars in Oregon and is expanding plantations on leased and owned land in Washington. And Boise Cascade Corporation has begun a hybrid poplar program in the state of Washington.

These plantations should provide information regarding the cost and potential of these crops. Pulp mills estimate a $60 \%$ yield of fiber and a $40 \%$ yield of fuel from the harvested biomass. Under current economic conditions, the energy yield from fiber plantations can be estimated at about one-third of the recoverable biomass (Sims et al. 1991).

In the public sector, Oak Ridge National Laboratory (ORNL) has coordinated the DOE effort to develop biomass plantations for energy. DOE hopes these plantations will be major contributors to the biomass energy supply, providing up to $15 \%$ of the total biomass potential by 2010 . Development at several SRIC locations has been directed at finding suitable species and harvesting techniques (see Figure 11). Land costs, feedstock costs, water, and the method of commercialization appear to be the principal limitations to widespread use. ORNL has established that there are from 35 to 70 million acres of land potentially available for SWRC production (Wright and Ehrenshaft 1990). Although current production costs are twice the market value of fuel, DOE has targeted a $50 \%$ reduction in costs through improved production and harvesting techniques to lead to an economic advantage for energy in biomass plantations (Wright 1990; Solar Energy Research Institute 1990).

Environmental concerns associated with SRIC include fertilizers, disease, soil erosion, water pollution, and pesticides. These are being evaluated in environmental assessments and workshops conducted by ORNL for EPA (Braunstein et al. 1981; Cantor and Rizy 1991; Graham 1991; Ranney 1991).

Biomass plantations have been used as a filter or sink for nutrient-laden pulp mill sludge, municipal sludge, and food processing wastewater. They have also been used in urban woodlots where municipal sludge is applied to grow media for composting. After 10 years of experience, one municipality found that plantation wood was an expensive substitute for other composting media. The juvenile plantation wood was expensive to grown in a small plot, even with sludge; moreover, the juvenile wood degraded rapidly. Although it solved an environmental wastewater problem, the wood was not a very economic source of fiber (Bockheim et al. 1988; Brockway 1988; Crooks 1988; Lea and Fredrick 1991).

A tomato processor in California has used a eucalyptus plantation to absorb process wastes during the harvest season. Although it was not originally intended to produce fuel or fiber, the plantation may be expanded as these markets develop (Turnbull 1991).

A significant question regarding fuel supply from plantations is the infrastructure: who will develop and manage the plantations? If it is to be the private sector, then during the next 20 years wood will be grown primarily for fiber. The wood products industry will seek to procure agricultural land with abundant water at low cost for fiber production. Thus far, utilities have shown no interest in managing large-scale plantations for power stations. 


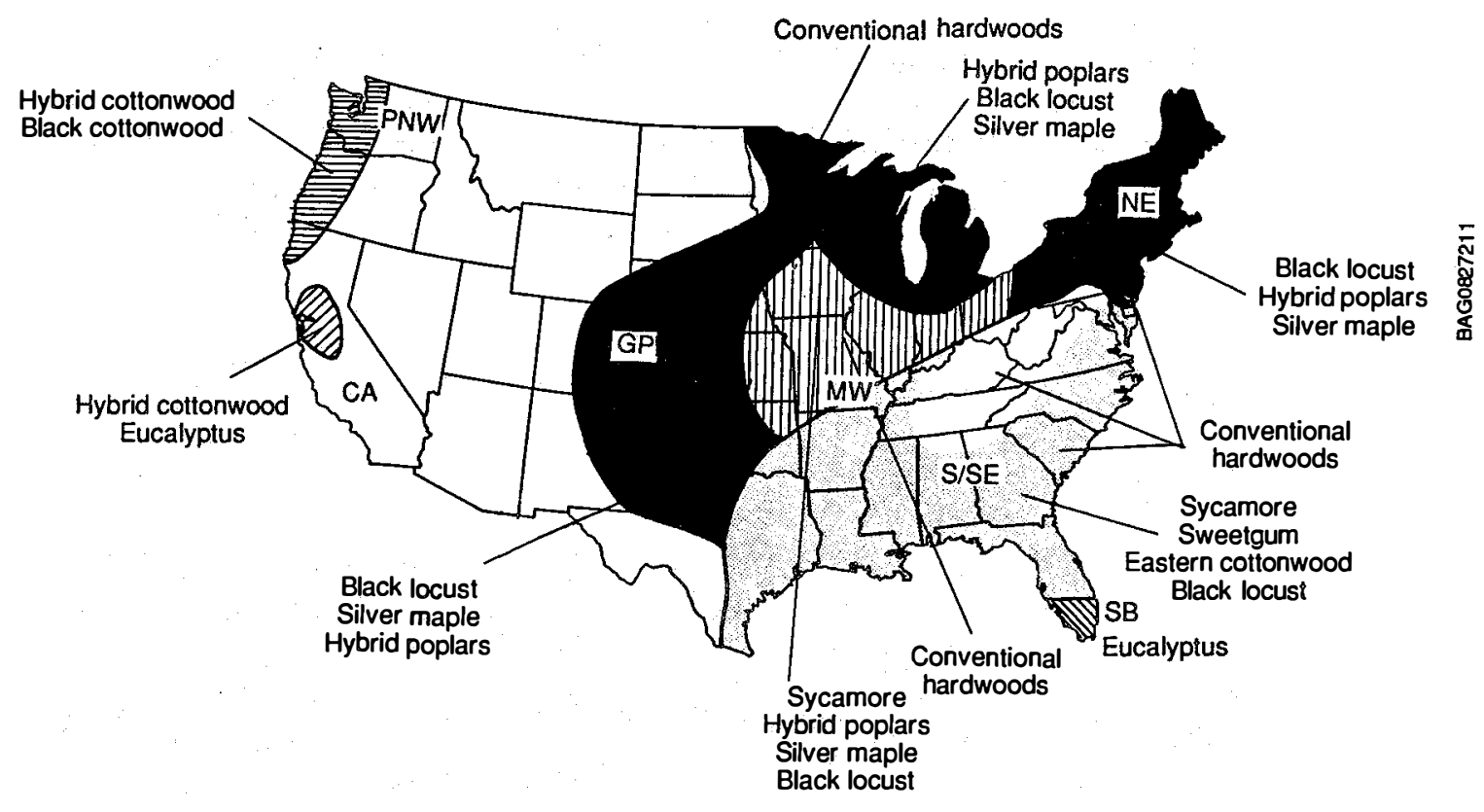

Figure 11. Species for evaluation of short-rotation woody crops Source: Wrlght and Ehrenshaft 1990

Although the DOE has focused on plantations for energy, the forest industries are primarily interested in pulp. A difference in priorities between fiber and fuel could lead to problems of direction in plantation research. Most experts assume that the two products are complementary. And both groups are concerned with the environmental suitability of plantations and their potential use to improve soils, water quality, and habitat. A memorandum of understanding (MOU) was concluded between the USDA and DOE in 1991 that includes the goals of advancing environmentally sound energy production from agricultural, forestry, and alternative energy resources and assessing the impact of energy production on the environment (USDA-U.S. DOE 1991).

\section{Biomass Fuel Classification}

A significant lack of reference data on the heating value, ash fusion characteristics, and mineral composition of fuels in each region currently makes it difficult to associate potential environmental concerns with fuel types. For example, some biofuels such as animal wastes are high in nitrogen and sulfur, which can cause excessive $\mathrm{NO}_{x}$ and $\mathrm{SO}$ emissions. Variations exist between biofuel types and species that make them more suitable for conversion in a methane digester, for example, than in a combustor (Bushnell et al. 1989).

Reference data that characterizes biomass fuels according to environmental benefits would be most valuable to a plant engineer who is planning pollution abatement equipment. A sample or analysis 
submitted by a single potential supplier could be compared with data from the surrounding region. A common set of fuels reference data could be used by plant managers who are often faced with opportunities to buy unfamiliar fuels but do not have the background information to anticipate the impact a fuel can have on their ash disposal or air quality permits. For example, whole tree chips from forest thinnings differ in operation, emissions, and ash chemistry from mill residues.

Several references contain chemical analyses of local biomass fuels. Information is more complete for some areas where systematic surveys have been carried out. The Electric Power Research Institute (EPRI) has issued a contract to compile existing biomass fuel data. NREL has published a compendium of methods of analysis for biomass and biomass conversion processes. By using these methods, a collection of fuel analyses could be identified by type and geography, similar to the Tables of Feed Composition and Analysis published by the National Academy of Sciences. Like fuel analyses, the "Tables" are used as reasonable estimates of nutritional value rather than exact values (Milne et al. 1990; National Academy of Sciences 1969).

A fuel classification would list fuels according to conversion and environmental characteristics. Once the range of fuels and feedstocks has been characterized, it would be possible to classify fuels according to their suitability for different conversion processes. These findings and criteria could then be compared with industry experiences.

Using the classification, a region could be surveyed for fuels suitable for new and efficient processes, such as gasification for gas turbines. Or sites could be identified that require conversion processes with inherent fuel or feedstock flexibility, like pyrolysis or liquefaction, to offset the impact of changes to the natural or economic environment that affect fuel supply. 


\section{Environmental Implications of Increased Biomass Use}

As described above, biomass use is expected to increase with changing economics. It is estimated that 14.8 quads of biofuel could be used by the year 2030 by applying accelerated research, development, and demonstration to efficient technologies. It would require intensive management of timber and 192 million acres of unused cropland, primarily in the Midwest, South, and southeastern United States. This represents an increase of approximately three times current biomass use.

Biomass fuels in the future will be similar to those used today. Woody fuels from forest and cropland would increasingly supply industrial and electric applications. Wood residue fuels will continue to deteriorate in quality as wood is reallocated to growing fiber markets. Residue supply will be supplemented by increased forest harvesting and plantation species. Agricultural fuels will be used if warranted by local economics and technological advances. Urban wood use will continue. Transportation fuels will be produced from biomass plantations. New resources, enough to produce more than 10 quads, will derive from intensive management of timberland and intensive cultivation of cropland.

Some effects, such as the impact of harvesting on habitat or air pollution from residential wood combustion, draw attention to the potential costs of biomass energy. The bioenergy community must address these large-scale environmental issues before public pressures limit the use of biomass technologies. Projects are sometimes opposed because of concerns that the environmental costs of biomass conversion to energy may be significant. It is a purpose of this review to identify which of these areas of environmental concern have been adequately addressed and what areas still need study or clarification. Some major topics are listed in Table 3, according to the type of environmental impact.

\section{Environmental Reviews}

Concern for the environment has generated a wealth of literature on the development and use of biomass for energy. Many aspects of biomass production and conversion have been studied, and some have been conclusively addressed or are being currently addressed by many organizations.

Several environmental studies appear in the project lists and publications of state and local governments, which are sometimes funded by DOE regional programs. As described previously (see Table 2), these organizations have developed resource surveys and analyses, directories of biomass facilities, guidelines for environmental permitting, and projections of future supply and demand (Bonneville Power Administration 1989; CONEG 1989).

At least two regions have prepared generic outlines of environmental impacts for biomass energy. California prepared a declaration of negative environmental impact for several biomass energy demonstration projects (Envirosphere 1982) and the Tennessee Valley Authority (TVA) evaluated the regional environmental impact of biomass conversion facilities (Bohac 1986). Although generic impact statements help to encourage the location of biomass facilities in a particular area and to offer policy alternatives designed to encourage biomass use, the purpose of an environmental analysis, declaration of negative environmental impact, or environmental impact statement is to identify those elements appropriate to a specific site rather than to a technology. 


\section{Table 3. Environmental Topics Important to Increased Biomass Use}

$\begin{array}{lll}\text { Impact/Category } \quad \text { Needed } & \text { Addressed }\end{array}$

Production and

Land Use

Soils/

Productivity

Institutional and Social

Water Supply

Water Quality

Wildlife and Ecosystems

Air Quality

Conversion

Land Use

Solid Waste Disposal

Institutional and Social

Water Supply/

Water Quality

Air Quality
Local land suitability for intensive forest or woody crop production. Conversion of former wetlands.

Long-term residue effects. Long-term modeling and validation. Effect of whole tree harvesting.

Public policy and planning. Farmer changes to woody crop production, economics, social. Information systems, GIS, etc.

Benefits/impact of increased production on water supply. Needs for water supply development.

Impact of intensive cultivation. Fertilizers, pesticides, disease. Cropland conversion.

Impact/benefits of increased shift from agriculture to woody crops or forestry.

Regional impact.

Solve operational problems of burning offset fuels.

Plant siting logistics.

Permitting for urban wood fuels.

Large-scale biomass facilities.

Needs for water supply development. Limits to water use, local.

Regional impact. Emissions and fuel classification $\left(\mathrm{NO}_{\mathbf{x}}\right)$.
Global availability.

Effect of residue removal.

Reactions to potential increases.

Coordinated planning systems.

Global problem definition.

Erosion protection, benefits.

Nonpoint source pollution.

Legislation, habitat conservation areas.

Ambient regulation. Emissions offsets for open burn.

Environmental permits, assessments.

Facilities directories. Resource assessment.

Facilities regulation. Management and reuse/recycle.

Facilities regulation.

Environmental impacts are recognized but not detailed in technology-based assessments. A wide variety of studies are available that list environmental impacts. These include methodologies, all technologies, specific technologies, demonstration case studies, and entire regions. There is one comprehensive regional assessment for the 13 states in the TVA. Several checklists or guides 
to environmental permits of specific technologies havebeen outlined for DOE regional programs (DiNovo et al. 1978; Braunstein et al. 1981; Envirosphere 1982; Barnett et al. 1985; Bohac 1986; Brown et al. 1986; Smith 1987; O'Leary 1988; Munasinghe 1989; Noteware 1989; Cantor and Rizy 1991; Ranney 1992).

Some assessments have attempted to rank the negative impacts of biomass utilization in order to determine the policies and priorities (Braunstein et al. 1981; Bohac 1986; Cantor and Rizy 1991). A checklist of environmental issues related to biomass use for energy is reviewed in a recent literature survey as risks of biomass energy development, shown in Table 4 (Cantor and Rizy 1991). The relative importance of production and of harvesting and conversion technologies to major environmental impacts is illustrated by a technology review by ORNL, shown in Table 5 (Braunstein et al. 1981). Discussions at bioenergy forums suggest that public policy, concerns of grass roots environmental groups, residential wood combustion, harvesting issues and nutrient loss, and fuel characteristics such as hazardous constituents are the most important environmental challenges for biomass energy development.

\section{Biomass versus Fossil Fuels}

As a renewable resource, biomass production, compared with fossil fuels, benefits the environment, particularly its potential to maintain or restore the environment and to mitigate global climate change. Biomass burning, for example, is a moderate contributor to ultraviolet absorption, radiation, and visibility, but it is not a controlling factor of major importance like petroleum or coal combustion. It does not contribute to the problems of acidity, oxidation, or oxidants to the degree of the fossil fuels (Helm 1990; Graedel 1990). The 1990 Clean Air Act recognizes the benefits of biomass combustion by providing incentives to coal burning utilities to use biomass (Turner 1991).

Table 4. Environmental Risks Associated with Biomass Energy Source: Cantor and Rlzy 1991

Deforestation

Wood combustion

Fertilizers, pesticides, herbicides

Competition with food production

Irrigation

Ecological diversity

Soil erosion

Nutrient depletion

Sedimentation

Dust emissions 
Table 5. Suggested Negative Impacts Associated with Biomass Utilization Scaled Very High (VH) to Very Low (VL)

Source: Based on Braunsteln et al. 1981

\begin{tabular}{|c|c|c|}
\hline Impact/Category & Production and Harvesting & Conversion Technologies \\
\hline Land Use & $\begin{array}{l}\text { Silvicultural plantations } \\
\text { Agricultural plantations }\end{array}$ & \\
\hline Soils & Agricultural residues & \\
\hline Institutional and Social & $\begin{array}{l}\text { Silvicultural plantations } \\
\text { Agricultural plantations } \\
\text { Marine biomass }\end{array}$ & Fermentation, herbaceous, large \\
\hline Air Quality & & Wood combustion, small scale \\
\hline Land Use & $\begin{array}{l}\text { Freshwater biomass } \\
\text { Marine biomass }\end{array}$ & \\
\hline Soils & $\begin{array}{l}\text { Silvicultural plantations } \\
\text { Agricultural plantations }\end{array}$ & \% \\
\hline Institutional and Social & Wood from residues, forests & 3 \\
\hline Air Quality & $\begin{array}{l}\text { Agricultural residues } \\
\text { Agricultural plantations }\end{array}$ & $\begin{array}{l}\text { Agricultural residue combustion } \\
\left(\mathrm{NO}_{\mathrm{x}}\right)\end{array}$ \\
\hline Water Quality & $\begin{array}{l}\text { Agricultural residues } \\
\text { Agricultural plantations }\end{array}$ & \\
\hline Wildlife and Ecosystems & $\begin{array}{l}\text { Silvicultural plantations } \\
\text { Agricultural plantations } \\
\text { Marine biomass }\end{array}$ & $\therefore$ \\
\hline Soils & $\begin{array}{l}\text { Silvicultural plantations } \\
\text { Agricultural plantations }\end{array}$ & \\
\hline
\end{tabular}

Medium

Solid Waste Disposal

Soils

Institutional and Social

Air Quality

Water Quality

Wildlife and Ecosystems
Wood from residues, forests

Freshwater biomass

Wood from residues Silvicultural plantations

Wood from residues Silvicultural plantations Freshwater biomass

Wood from residues Freshwater biomass
Gasification, large scale Liquefaction

Anaerobic digestion, large scale Fermentation, large scale

Wood combustion

Wood combustion, large scale Fermentation, large scale

Gasification

Fermentation

Wood from residues 


\section{Production and Harvesting of Biomass Feedstocks}

Increased biomass use will require improvements to the supply infrastructure-the production, harvesting, and transportation. Source-related concerns arise from biomass production, cultivation, and harvesting. Here, the principal concerns are with impacts on the natural ecology and habitat and effects on microclimate, soil loss, and water quality. Specific concerns frequently include increased transportation, noise, and odor; potential destruction of habitat; increased erosion; deterioration of water quality; depletion of nutrients; and deterioration of air quality. Environmental benefits that are recognized include uses for field and forest residues; opportunities for the use and rehabilitation of idle croplands; opportunities for the intensive management of forest lands; watershed protection through reforestation; and opportunities to mitigate global climate change.

Wood Residues, Timberland. Many studies have focused on forest management and the environmentally sensitive operations of harvesting biomass for energy (Table 2) Johnson et al. 1987; Bonneville Power Administration 1989; CONEG 1989). Alternative management systems have been conducted and evaluated on public and private lands for several years. Most of these studies are conclusive only for specific sites or circumstances. It is apparent that some potential problems can be managed without damage. Sometimes there have been improvements in site productivity and associated environmental impacts from biomass production (Snider and Miller 1985; Little and Waddell 1986; Johnson et al. 1987; Cline et al. 1990; Biologue 1990). These studies could be used to develop management practices suited to particular ecosystems. However, they are often not coordinated toward the development of management guidelines.

Short-Rotation Woody Crops. Environmental aspects of SRIC are now being studied by ORNL for DOE. At a recent workshop, several issues for existing forestry were identified, including bottomland forest conversion to agriculture; bottomland forest degradation; use of herbicides in forest regeneration; and erosion resulting from roads and harvesting. In terms of biomass energy crops, the focus was on disease, herbicides, and erosion. It was concluded that there was a lack of uniform data regarding the use of either mixed or dedicated species (Graham 1990).

The environmental impacts of intensive culture of herbaceous and woody crops, biomass harvesting techniques, and whole tree harvest burning should be assessed. This would include the identification of water quality and water quantity benefits from biomass energy production. The benefits of promoting the development of new biomass resources through cooperative strategies, resource banking, and demonstration plantation or reforestation programs should be evaluated. Some experts regard plantations as introducing diversity into the monoculture of agricultural cropland; others see the dedication of large tracts to woody crops as a threat to biodiversity (Cantor and Rizy 1991).

Local and state agencies are in a position to make information about the environmental benefits of intensive forestry (short-rotation) or energy crops available to local forestry and agricultural extension agents, utilities, and power producers. At present, this information has been limited (USDA Forest Products Laboratory 1990; Nakamura 1990).

Institutional and social aspects of growing energy crops include organization of water resources for crop production and introduction of new crops to existing farm populations. Although the development of the fossil resources in the West will take substantial water resources, biomass development will be similar (Braunstein et al. 1981).

Biomass energy crops are new. By using the CRP program described previously, a farmer, average age of 60 , is paid a rent and can receive cash for crops, rather than invest in or learn how to grow new crops such as switchgrass or short-rotation trees. An alternative is to lease land to private firms for production, an approach used by western pulp mills. This is an area that needs to be studied. 
Local development of large-scale biomass energy crops may require the use of proven planning systems. Several systems are available. Those used by the Vermont Environmental Council, Maine Audubon Society, Nevada State Multiple Use Local Advisory Committee, and local or state departments of forestry and agricultural extension such as coordinated management and planning (CRMP) are cited as examples (Anderson 1990; Anderson and Baum 1987a,1987b). Management systems such as the GIS-based resource evaluation procedure could also provide the policy basis for SRIC (Hale et al. 1991).

Soil and Water. Soil and water issues are central to timber management, timber engineering, and road construction. Methods of harvest and cultivation that minimize soil compaction and reduce erosion, sediment transport, and chemical use are abundant in the literature references and employed in the development of woody biomass crops intended for energy (Brown 1989).

There are arguments that long-term soil fertility and productivity have not received adequate attention in forest or agricultural land management. These discussions and the need for ongoing research and development are not unique to the growth of biomass for energy, but are also shared by production of food and fiber (Braunstein et al. 1981; Waring and Schlesinger 1985; Maser et al. 1988).

There are few examples of strategies to use biomass fuel production as a means to improve local ecology. Poplar has been used as a filter for agricultural runoff (Biologue 1990). Biomass energy projects to reforest watersheds to improve infiltration and prevent erosion are isolated and not generally reported. There have been proposals to use herbaceous fuel crops that can selectively remove salts from saline soils.

Energy production is another reason to support environmental studies to develop appropriate strategies that could improve wetlands and water quality through biomass production. These projects would complement other watershed protection techniques, lands restoration, and reforestation (Land and Water 1991).

Productivity, Ecology, and Nutrients. Issues of nutrient cycling and removal in biomass production are addressed in many studies (Menke 1979; Smith et al. 1986). However, information about nutrient removal from different methods of harvesting is still incomplete. In a Vermont study, for example, whole tree harvesting removed 2 to 16 times as many nutrients as conventional logging (Braunstein et al. 1981). This kind of study must be applied to new proposals for whole tree production and harvesting. Studies have shown that site productivity impacts of whole tree removals can be extremely site and species specific.

Computer simulations like SEMS, Forcyte, and others have been developed and validated to simulate the effects of biomass harvesting on particular forest types (Kimmins et al. 1989; Sachs et al. 1989). They indicate the potential impact of management techniques on long-term productivity. So far, they have not been used extensively for forest management because of the difficulty of validation. Also, they have apparently not been applied to techniques for fertilization. Coordination of computer simulation and validation by field studies will be essential to intensive management of existing forests.

Chemicals from fertilization, disease, and pest control are potentially a major impact of intensive management. New theories of forest and agricultural fertilization have been proposed to help reduce excessive use of chemicals and the need for pesticides and herbicides (Torsten 1991; Adler and Schwengle 1991). However, these systems will develop slowly until they can be clearly demonstrated. 
Basic guidelines for the quantitative assessment of resource availability, biomass harvesting, and fiber allocation need to be developed. Some areas, such as the Pacific Northwest, have included biomass fuel in general models for forest productivity and the allocation of forest products. Some of the information developed since 1970 includes environmental impacts and limits to removal and productivity. Foresters claim, however, that site data are still insufficient to establish clear management guidelines (Howard 1990). Ongoing studies at the Pacific Southwest Forest and Range Experiment Station are expected to define criteria and practices for the different ecological subsystems of California, Arizona, and Nevada (Center for the Conservation of Genetic Diversity 1991).

Although the potential of crop and forest residues has been estimated by using coefficients, guidelines for residue removal must be specific to crops, species, and circumstances. Local resource managers historically have cooperated with farmers and landowners to develop long-term environmental practices to assure site productivity. Utilities and timber companies that employ environment and resource management specialists who seek to carry out sustainable biomass production will have a positive impact on the environment, while still hedging against interruptions or limitations to biomass supply. Nevertheless, it is clear that there are still many unanswered questions about the effect of biomass harvesting for energy on forest soils.

Wildlife Habitats and the Natural Environment. One sensitive environmental area is the impact of biomass production and harvesting on wildlife habitats and the natural environment. It is in this area that goals of supporting renewable energy conflict with opposition to forest harvesting. Specific assessments of biomass harvesting impacts on habitat were not found. However, some studies are in progress for the development of SRIC woody crops.

Table 6 lists the number of plant and animal species that are listed as endangered or threatened following the Endangered Species Act of 1973. More than 500 of the 1141 species currently listed are endangered. "Endangered" are those species in danger of becoming extinct throughout all or a

\section{Table 6. Plant and Animal Species Listed as Threatened or Endangered, by DOE Region} Source: Broussard 1991

\begin{tabular}{lcc}
\hline Region & Number of States & Number of Species \\
\hline Northeast & 11 & 122 \\
Great Lakes & 7 & 86 \\
Southeast & 13 & 432 \\
West & 13 & 386 \\
Northwest & 5 & 59 \\
Hawaii & 1 & 56 \\
Total & 50 & 1,141 \\
\hline
\end{tabular}

Notes: Endangered Species Act of 1973.

"Endangered" are those in danger of becoming extinct throughout all or a significant portion of their range. More than 500 species of plants and animals are listed.

"Threatened" are those likely to become endangered. 
significant portion of their range. "Threatened" are those likely to become endangered (Broussard 1991). Habitat and natural ecology are clearly important considerations in any biomass development plan.

Habitat studies have shown that the forest service and national parks are largely responsible for the return or increased populations of large animals. However, development or rehabilitation of riparian habitats and habitats for small mammals must be addressed at the local level, because jurisdiction resides with the state agencies (Thomas 1990).

A system of habitat conservation areas was proposed by an Interagency Scientific Committee (ISC), composed of the heads of the National Park Service, United States Fish and Wildife Service, USDA Forest Service, and Bureau of Land Management, to develop strategies for the northern spotted owl on federal lands. The Endangered Species Act and Oregon's Forest Practices Act require that the State Board of Forestry draft conservation plans and management guidelines for state and private lands in Oregon. The ISC conservation strategy recommended that "the management of suitable habitat on private lands and State lands should be carried out under the leadership and cooperation of private land owners. . . . The states with their cooperators would prepare habitat conservation plans." The problem of fragmentation and loss of habitat is clearly important (Greber et al. 1990).

Although some groups advocate creation of urban habitats, development of energy plantations and woodlots have not been promoted as land use blocks to create habitat, restore lost habitat, or link existing blocks through conversion to farmland from forested areas. Rather, the potential danger of conversion of large areas to biomass production has been raised (Cook et al. 1991). Riparian habitats from forested wetlands could also be created (Ice et al. 1989).

Modeling and management tools should be directed at the management of biomass production and harvesting to improve, protect, or conserve habitats and natural ecology. For example, advances in computer modeling that use expert systems and neural networks to recognize patterns are being employed to model wildlife habitats in Texas. These developments should be employed to assist in developing wildlife management on biomass production areas.

Public agencies and private sector parties should consider cooperation with advocacy groups on specific land use and energy-related projects to develop sound technical bases for management decisions and to develop strategies to increase water availability and habitat by developing and using biomass energy resources.

State and private forestry groups should look at energy crop or forest management techniques that specifically improve the protection of riparian areas and small mammal habitats not protected by national forest plans. They should also explore methods and incentives to increase biomass production on privately owned agricultural and boundary lands, which could be directed to improve wildlife habitats and water supplies.

\section{Biomass Conversion}

End use concerns can be disperse, such as air pollution from residential wood combustion; or concentrated, as the more closely regulated impacts of industrial cogeneration facilities, power plants, and other conversion facilities. They often include local air quality, odor, noise, increased transportation, and pollution of the land. Environmental benefits often cited include productive use of industrial wood and pulp mill residues and urban biomass residues, conversion of a renewable resource to energy, and opportunities to mitigate global climate change. 
Residential Wood Combustion. Residential wood combustion (RWC) has become a major biomass consumer, especially in the Northwest and New England, where it competes for fuel with power plants and industrial biomass consumers. The development of improved combustors and pollution control devices for RWC and its impact on air quality have been studied in detail. In many cases, RWC has negative air quality impacts on urban air quality and forest ecosystems. In 1986, for example, residential combustion contributed more than $10 \%$ of atmospheric carbon monoxide (Council on Environmental Quality 1989). Since then it has come under state and national regulation.

Sometimes RWC inhibits use of industrial biomass by filling an airshed with fine particulates. Some industrial projects have been delayed or stalled until absolute levels of fine particulates, measured by ambient monitoring filters, are reduced. Communities in Montana, Colorado, Washington, and Oregon have suffered curtailment of residential combustion during certain climatological conditions that concentrate the respirable particulates in airsheds. In some cases, air pollution from RWC has precluded development of additional biomass combustion facilities, even at wood product industries. Some Northwest communities have reversed incentives for biomass in favor of electricity and natural gas in order to reduce air pollution (Burnet 1987; Cantor and Rizy 1991).

In most areas, improvement of RWC has been supported through the cooperation of industry associations and federal and state agencies. Efforts should continue to support systems and policies to reduce emissions from residential wood combustion, increase efficiency of wood stoves in use, and decrease the impact of uncontrolled residential fuel harvesting on biomass stands.

Industrial Biomass Facilities. Biomass energy projects include a range of conversion facilities from combustion, gasification, and anaerobic digestion to liquid fuels. More than 3000 facilities convert biomass to energy, including more than 200 power plants, 35 gasifiers, 300 landfills, and 60 ethanol plants (Solar Energy Research Institute 1990). Many areas, through the regional programs, have determined the potential number and location of conversion facilities under current resource availability. The environmental costs and benefits of conversion facilities are better understood than the environmental impacts of the demand they create for biomass production and harvesting (see Figure 12).

There have been many site-specific environmental assessments to permit conversion plants and their waste disposal. Although these assessments are useful for individual sites, it is difficult to derive from them a generic biomass conversion environmental impact statement, or "green plan," because regulation often depends on the circumstances of a particular airshed or watershed.

Information is available to help site biomass plants. During development and construction, biomass plants must pass a series of environmental analyses, regulated by EPA and subsidiary organizations, according to the condition of the local airshed and watersheds. Regulation by agencies is considered expensive, but does not generally prevent biomass use. Biomass conversion facilities are subject to the same environmental controls as fossil fuels. However, biomass energy is viewed as a low-impact alternative compared with fossil fuels, especially coal. The exception is RWC, which poses air quality problems in a growing number of localities (Miles et al. 1984; Tennessee Valley Authority 1989; Helm 1990; Council on Environmental Quality 1989).

A guidebook prepared for the Bonneville Power Administration contains a good review of the environmental considerations faced by a facility planning to convert biomass to energy (Vranizan et al. 1987). Other states and regions have developed similar guidelines that enumerate individual plant systems. These references point out environmental benefits of biomass conversion facilities, including solid waste reduction through conversion to energy, pollution reduction through prevention of air pollution from open burning of agricultural or forest residues, conservation of nonrenewable fossil fuels, and the controlled reduction of feedlot runoff and subsequent pollution of streams. 

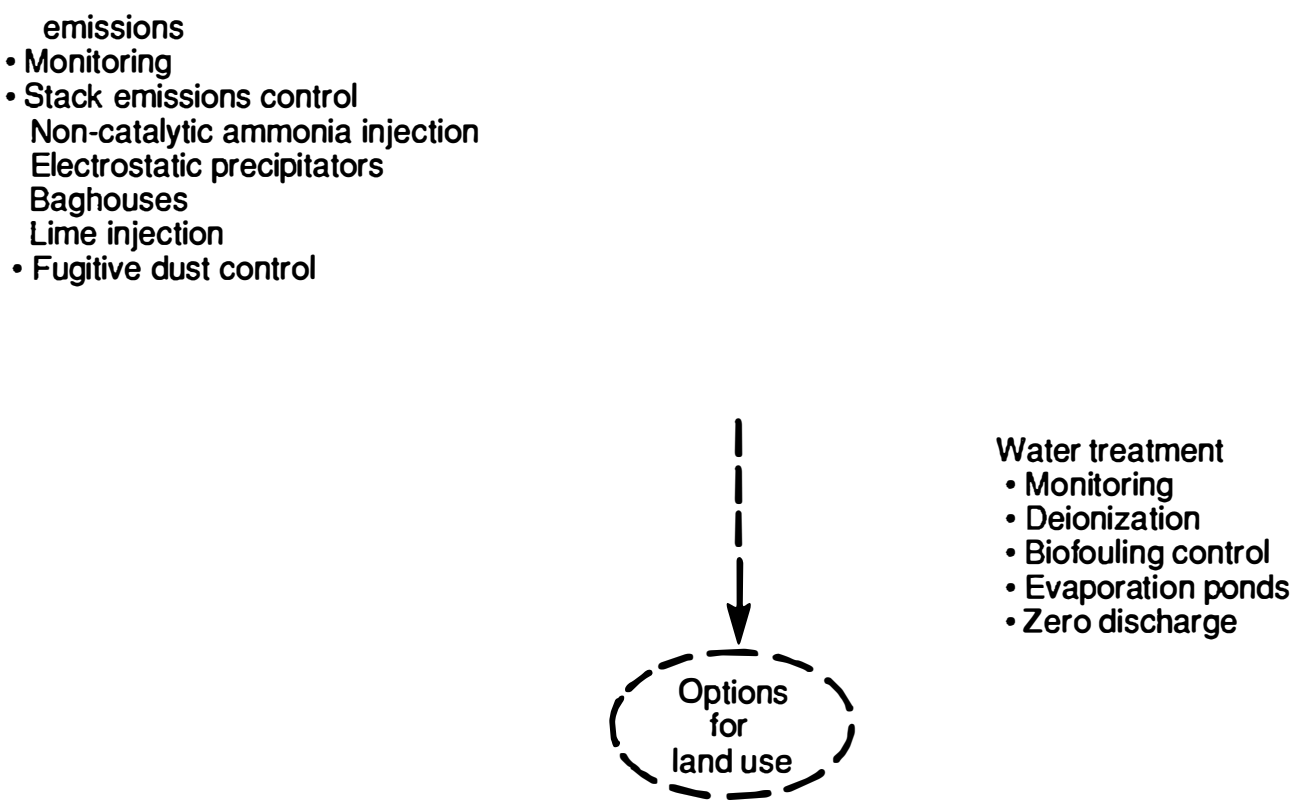

Figure 12. Environmental considerations associated with biomass use Source: Pacific Gas and Electric Company, San Ramon, CA, 1990

Air and water quality are typically the most significant impacts associated with biomass conversion facilities, followed by noise, dust, and odor. As shown in Table 7, the significance of environmental impacts has been described by plant operators (Kennel 1984).

Recent air quality concerns with biomass combustion have been with particulate emissions, $\mathrm{NO}_{\mathrm{x}}$, $\mathrm{SO}_{\mathrm{x}}$, and products of incomplete combustion. Residential and industrial wood combustors, especially plants with fuel dryers, emit volatile organic compounds and fine particulates (Herrera et al. 1989; Wellman and Butchino 1989; Wilhelm and Simbeck 1990; Muir 1991; Turner 1991).

Air quality equipment can account for $15 \%$ to $20 \%$ of the direct capital costs of a biomass power plant, and even more in waste-to-energy facilities. Equipment is even more costly if biomass is co-fired with MSW because of the potential emissions of toxic substances or heavy metals. Environmental costs are recognized as significant in both the capital cost and long-term liability of operating a biomass facility, especially because recent air quality legislation has given the EPA veto power over local authorities by changing the permit process (Turner 1991; Jones 1990).

Water quality considerations include leachate from biomass storage piles, residual ash from combustion, boiler cooling water, blowdown from boilers and cooling towers, and wash water, storm water, or runoff. Wastewater discharge permits are usually obtainable, sometimes after on-site water treatment. Some districts require complete wastewater treatment on site, sometimes referred to as "zero discharge." New plants employ cascaded water use, where wastewater is sent to the point of maximum beneficial reuse, as at the 40-MW wood-fired plant in Stanton, Maine (Strauss 1991). 
Table 7. Environmental Issues for a Biomass Power Plant in Order of Importance Source: Kennel 1984

$\begin{aligned} \text { 1. } & \text { Residential firewood competition } \\ \text { 2. } & \text { Air quality } \\ \text { 3. } & \text { Noise } \\ \text { 4. } & \text { Truck traffic } \\ \text { 5. } & \text { Water use } \\ \text { 6. } & \text { Ash disposal } \\ \text { 7. } & \text { Wastewater disposal } \\ \text { 8. } & \text { Visual effects } \\ 9 . & \text { Forest effects } \\ \text { 10. } & \text { Socioeconomic effects } \\ \text { 11. } & \text { Land use }\end{aligned}$

Solid waste permits include boiler ash and sludges if wet scrubbers are used. Whenever possible, the ash is used as a soil amendment, providing mineral nutrients and increasing the $\mathrm{pH}$ of acidic soils. About $75 \%$ of biomass ashes are landfilled or land applied. The ash must be plowed into the soil promptly to avoid fugitive dust problems. Hazardous or toxic constituents of solid wastes are sometimes detected when urban wood wastes or treated woods are used as part of the fuels. In these cases, the material must be hauled to a special landfill, which is often quite expensive (Campbell 1991; Folk and Campbell 1991).

Local noise and odor regulations also apply to biomass production facilities. In most cases, these problems have been resolved through appropriate siting and proper drainage and ventilation of fuel storage piles. Wood waste piles of hardwood species with degradable sugars are most susceptible to odor problems.

Environmental impacts are typically documented during the permitting and design process so that facilities will comply with environmental regulations. Several case studies are available. It was not the focus of this study to examine environmental impact statements in detail; however, several have been required for biomass plants. Currently, it is difficult to identify important environmental considerations by examining existing facilities. A system to locate and use technologically sound environmental assessments in major use areas would help to assess the impacts associated with different conversion processes. A bibliography or reference list of known biomass environmental impact statements and reviews for biomass energy facilities would be useful to planners and developers.

There has been some concern that biomass energy conversion facilities are not treated in the same way as other wood and biomass processing facilities. It is claimed that new plants are at a disadvantage because they are regulated more stringently than renovations of existing facilities. Although difficult to document, this has been cited as an important barrier to bioenergy development.

\section{Global Climate Change}

Several recent studies consider issues related to biomass energy and potential global climate change. Environmental strategies for biomass energy include replacement of fossil fuel and production of biomass to capture $\mathrm{CO}_{2}$ for long-term storage. In general, the overall impact of reforestation 
programs is expected to be small relative to the potential global climate change (U.S. Congress 1991). However, as long as biomass is being produced at the rate it is being used, it should cause no net change in the carbon balance. The literature about global climate change is prolific, and currently strategies tend to favor replacement of biomass for fossil fuels (Elliott and Booth 1990; Legget 1990; Musselman and Fox 1991; Overend 1991; Oregon Department of Energy 1991)

Concerns for global climate change and associated environmental impacts have been included in the 1990 Farm Bill and in the Clean Air Act legislation and are reflected in the administration of laws such as the 1973 Endangered Species Act. A new Office of the Environment has been created in the USDA, and integrated environmental themes are reflected in priorities of USDA Cooperative Extension agents in agriculture, forestry, and range management.

Some studies evaluate intensive biomass cropping as a means to mitigate global warming (Wright et al. 1990). At least one agency attempted to introduce carbon taxes on fossil fuels to encourage the use of biomass energy. Strategies designed to increase carbon uptake and storage will increase the supply of biomass available for energy conversion. These can include planting unstocked timberland; replanting underproductive timberland; converting agricultural lands to forestry; planting available urban areas, parks, parking strips, and unused lands; fertilizing nonfederal timberlands; and thinning overstocked, stagnated lands (Oregon Department of Energy 1991).

Projects and strategies that increase the energy efficiency of biomass conversion processes will also reduce global climate change. These strategies include improving existing underproductive areas, underutilized timberland, and unproductive agricultural land that could be used for environmental benefits. Growth of biomass has been considered as a carbon sink. Some local species, such as the alder tree in Oregon, have been considered to provide the biodiversity required for habitat. The results of some of these plans are being included in new strategies and have been introduced to legislatures (Oregon Department of Energy 1991; Sampson 1991).

The EPA evaluated three reforestation scenarios that have the potential to mitigate global warming: planting trees with no harvesting, traditional forestry, and SRIC of trees for biomass. The study estimated $\mathrm{CO}_{2}$ cycling through the trees, other sources of $\mathrm{CO} 2$ and important trace gases associated with site preparation, tree planting, harvesting, and other activities specific to each scenario. Costs associated with each scenario were estimated, and the cost of using wood biomass as an alternative to fossil fuel was evaluated (Geron 1991).

The study used, as a base for comparison, 40.4 million acres of crop and pasture land that required erosion control in 10 geographical regions of the United States. Of these, the study found SRIC to be the best long-term solution because of both a high yield of energy feedstock and reduction in fossil fuel consumption. There will be more studies of this type, and information about techniques to mitigate global warming should be disseminated to local resource managers and energy converters. 


\section{Conclusions and Recommendations}

This broad review of biomass resources, fuels, and environmental impacts has generated many potential themes, ideas, and areas for further evaluation. The production, harvesting, and conversion of biomass affects many aspects of the environment. Biomass energy must share the burden of mitigating this impact with the producers of food and fiber.

This overview shows that generalizations about environmental impacts are not very useful outside a clearly identified ecosystem because of the diversity of biological values and the range of food, fuel, and fiber uses of biomass. Because biomass energy cuts across several resource areas, it places the resource manager on a bridge between the traditional agricultural, forest, and urban landscapes. Thus, institutional cooperation in resource management is important both to protect and to improve the environment and to use biomass wisely. It is apparent that members of many organizations are capable of managing the environment with increased biomass use if they are provided with good information and granted a suitable political framework for action.

Use of biomass for energy, whether it be intensive culture on agricultural cropland, residential woodcutting, or industrial harvesting for large-scale energy use, represents a competing land-use group. The group's demands appear to the resource manager as those of another interest group to fit into increasingly integrated management plans.

In forestry, integrated-resource analysis is appearing at the national forest, local, and regional levels. Several state forestry organizations are mandated to integrate environmental planning with forest management. The many environmental impact statements specific to land use also address biomass projects. Biodiversity and landscape management are new resource management themes.

Biomass production and harvesting, through intensive forestry and woody crop cultivation, could have major environmental impacts. The DOE short-rotation woody crops program is attempting to address these issues with the interest and participation of private companies. Studies of intensive forestry impacts, however, appear to be stalled until budgets are available from agriculture or energy departments.

In agriculture, biomass energy should be developed in cooperation with the USDA Soil Conservation Service. The USDA programs to control erosion and conserve water bridge all uses of land within the conservation districts. They employ many proven resource management techniques, such as coordinated land use planning, which could be used to develop biomass resources for energy.

Environmental opportunities are created by the demand for biomass as fuel. Because this demand must be met by the production of biomass, it should be used to solve significant environmental problems involving agricultural land, riparian lands protection, open field burning, fire hazards to humans and wildlife, new ways to protect old growth, habitat development, and other resources in the ecosystem. Our review suggests that energy demands provide opportunities for the thoughtful development of additional biomass resources. Such development should ultimately improve ecological systems rather than constrain or damage them.

There seems to be a conclusion that many environmental impacts of increased biomass use can be mitigated through intensive management accompanied by research and development. Through good resource management, biomass energy development should improve water quality, urban solid waste disposal, and habitat and air quality. This review has identified several projects, policies, and actions that can be carried out by public agencies, resource managers, energy producers, and 
developers of biomass conversion systems. Development of systems, i.e., GIS and simulation, which improve management of both the environment and biomass production, are needed.

This review has shown that many environmental topics have been studied in detail. Those areas that involve regulation, such as air quality from open burning, residential combustion, and industrial conversion facilities, tend to be thoroughly investigated.

There is less information about those areas that are not regulated or are indirectly connected with energy recovery, such as wildlife habitats or water supply. No current programs appear to support continued research on soils, fertilization, and productivity. Proposed production technologies, such as whole tree harvesting and burning, must be evaluated for their long-term effects on productivity and soil development.

Environmental benefits of current biomass use include waste reduction and improved air quality. However, better information about biomass fuels and characteristics would aid the process. This would include investigation of better conversion systems for alkali-rich fuels such as crop residues and urban wood wastes. Societal benefits of agriculture offsets to reduce air pollution cannot be realized until technology problems are solved.

The most significant short-term impact of environmental protection on biomass energy production has been from regulating timber harvests by creating habitat conservation areas. Further research is needed to reduce risks to biomass supply by environmental regulation while preserving the diversity necessary to preserve natural habitats and productivity.

This review and recent forums on bioenergy suggest several agency, utility, and independent power producer activities to improve the environmental evaluation of biomass energy projects:

- Support cooperation between power producers and agricultural interests on harvesting and production. Environmental evaluation, goals, and objectives should be included in the projects.

- Support new methods for forest fertilization that will sustain growth without excessive chemical release and oversupply of nutrients to water bodies.

- Support the development of "landscape" management of resources that promises to increase the productivity of forest and agricultural land while improving environmental values. Techniques such as thinning and biomass harvesting are not universally suitable and must be balanced with the ecology and resources of specific sites. These should result in increased productivity on adjacent fields and forests.

- Perform ecological management studies that focus on "biomass" removal from forest stands, through field studies and computer simulation in order to develop appropriate management guidelines for individual stands and local circumstances. These studies will make major contributions to environmental protection. Many of these projects have been in progress but have not yet been applied in the field.

- Develop strategic plans for resource management systems that meet energy needs and maintain the integrity of ecosystems, their processes and functions, and the natural diversity of the biotic genes. These are the currently advocated concepts of landscape management.

- Establish goals for mitigating global warming, creating and preserving habitats, and other environmental benefits that can be obtained through energy resource development. 
- Provide environmental information to the public to enable it to make good decisions about biomass energy. This could include bibliographies or reference sources for environmental resource management and biomass energy conversion such as residential wood burning.

- Develop (energy producers) institutional strategies and become involved in public policy and resource management to ensure environmentally sound, reliable supplies of biomass for conversion. These may include environmental partnerships with advocacy groups on specific biomass-related environmental issues, projects, or problems.

- Participate (utilities and independent producers) in integrated resource planning in tributary watersheds. 


\section{References Cited and Recommended Reading}

\section{Biomass Resources and Energy Demand}

American Forestry Association. 1990. Natural Resources for the 21st Century. R. Neil Sampson and Hair, D., eds., Island Press, Washington, DC.

Associates in Rural Development, Inc. August 1986. Impact of Large Biomass Demand Centers on the Forest Resource Base. Report to the Northeast Regional Biomass Program, Applied Research and Technology Transfer Program. CONEG Policy Research Center, Inc., 400 N. Capitol Street, Suite 382, Washington, DC.

Biologue, 1990. "Regional Programs, EPA, NYSERDA and Canada Plan Wood Wastes Study." September/October, p.19.

Bonneville Power Administration. February 1989. Pacific Northwest and Alaska Regional Bioenergy Program, Yearbook. DOE/BP-1179, Bonneville Power Administration, Portland, OR.

Braunstein, H.M., Kornegary, F.C., Roop, R.D., and Sharples, F.E. 1981. "Environmental and Health Aspects of Biomass Energy Systems." Oak Ridge National Laboratory, in Fuels From Biomass and Wastes, Klass, D.L. and Emert, G.I. eds., Ann Arbor Science Publishers, Ann Arbor, MI.

Briedeman, R.I. and Fox, P. 1990. "Hog Fuel Price Analysis In The Pacific Northwest." Presented to the Wastes From Energy And Biomass Conference, Washington, DC.

Chum. H. and Overend, R. 1991. Working Notes for American Chemical Society.

Combs, S. May 1990. "Chipping To Recycle Wood Waste." Waste Age.

Conklin, F.S., Taylor, M., Miles, T.R., Miles, T.R., Jr., Davis, E., and McHugh, E.J. May 1991. Opportunities in Grass Straw Utilization: An Alternative Point of View. Agricultural Experiment Station Special Report 881. Oregon State University, Corvallis, OR.

Council for Agricultural Science and Technology (CAST). September 1990. Ecological Impacts of Federal Conservation and Cropland Reduction Programs. CAST Summary Report No. 117, CAST, 137 Lynn Avenue, Ames, IA.

Council on Environmental Quality. 1989. Environmental Trends. U.S. Government Printing Office, Washington, DC.

Council of Northeastern Governors (CONEG). April 1989. Northeast Regional Biomass Program Five Year Report: 1983-1988. CONEG Policy Research Center, Inc., 400 N. Capitol Street, Suite 382, Washington, DC.

Davis, J.M. 1991. "Bioenergy in the United States." Presented at the National Bioenergy Conference, March 19-21, 1991, Coeur d'Alene, ID.

Electric Power Research Institute (EPRI). 1990. Biomass Energy for Utility Applications. Workshop. October 24-25, 1990, Tampa, FL. 
Graham, R.L. December 1990. "Environmental Concerns Pertinent to Feedstock Production." Summary of Biomass Energy Strategies Workshop, interagency meeting held at Oak Ridge National Laboratory, Oak Ridge, TN.

Grasso, D.T. and Atkins, R.S. 1991. "The Composition of Recycled Wood Fuel: Environmental Permitting Implications." Presented to the IGT Conference on Energy and Wastes. Washington, DC.

Greber, B.J., Johnson, K.N., and Lettman, G. 1990. "Conservation Plans for the Northern Spotted Owl and Other Forest Management Proposals in Oregon: The Economics of Changing Timber Availability," Papers in Forest Policy 1, Forest Research Laboratory, Oregon State University, Corvallis, OR.

Hale, A.M., Marshall, W.D., and Scurry, J.D. 1991. GIS Policy Research. Geo Info Systems, Aster Publications, Eugene, OR.

Hinman, N.D., Schell, D.J., Tyson, K.S., and Goodman, B. May 1990. Resource Assessment and Economic Analysis of Important Region Lignocellulosic Feedstocks For The Production of Fuel Ethanol. Western Area Power Administration Project BF983232, Golden, CO.

Howard, J.O. October 1990. Biomass Estimates for Five Western States. Prepared by USDA Forest Service, Pacific Northwest Research Station for the Pacific Northwest and Alaska Regional Bioenergy Program, U.S. DOE.

Jenkins, Bryan M. 1983. Systems Analysis of Biomass Utilization. Report to Pacific Gas and Electric Company and Southern California Gas Company. University of California Davis, Agricultural Engineering Department.

Kennel, R.P. 1984. "Wood-fired Power Production: Financial, Legal, Institutional and Environmental Issues." In Energy From Biomass: Building on a Generic Technology Base. Proceedings of the Third Technical Review Meeting, November 27-29, Argonne National Laboratory publication ANL/CNSV-TM-157, Argonne, IL.

Klass, D.L. December 1990. "The Biofuels Industry." Chemtech, pp. 720-731.

Lee, K.H., Johnston, S.A., Stancil, W.D., Byrd, D.C. December 1990. Biomass State-of-the-Art. Prepared by the Research Triangle Institute for the Electric Power Research Institute, RTI Project Number 233C-3872-05-FR, P.O. Box 12194, Research Triangle Park, NC.

Lynd, L.R., Cushman, J.A., Nichols, R.J., Wyman, C. March 1991. "Fuel Ethanol From Cellulosic Biomass." Science, 251.

Meimban, J.J. III. and Govet, R.L. 1989. Assessment of Potential Targets To Use Biomass Resources. Final Report to the Idaho Department of Water Resources, Division of Energy, Boise, ID.

Miles, T.R. and Miles, T.R., Jr. March 1991. Urban Wood: Fuels From Landscapers and Landfills. Presented at the National Bioenergy Conference, Coeur d'Alene, ID.

Morris, G. May 1991. The California Biomass Energy Industry in 1990: Supply, Demand, and Outlook for Biomass Fuels. Pacific Gas and Electric Company, Department of Research and Development, 3400 Crow Canyon Road, San Ramon, CA. 
Oregon Department of Energy (ODOE) 1990. SB576 Working Group: Biomass Subcommittee Report. ODOE, Salem, OR.

Peak Environmental Management. 1991. Wyoming Biomass Inventory. Prepared for Energy Section, Department of Commerce, State of Wyoming, Cheyenne, WY.

Sampson, R.N. 1991. "Biomass Opportunities in the United States To Mitigate The Effects of Global Warming." Energy From Biomass and Wastes, Institute of Gas Technology, Chicago, IL.

Solar Energy Research Institute. March 1990. The Potential of Renewable Energy: An Interlaboratory White Paper. SERI/TP-260-3674, DE-90000322, Solar Energy Research Institute, Golden, CO.

Sifford, A. 1989. "Biomass Resource Assessment," U.S. Department of Energy Contract No. DE-FG7983BP35836, ODOE, Salem, OR.

Sims, R.E.H., Handford, P., and Bell, T. 1991. "Wood Fuel Supply And Utilization From Short Rotation Energy Plantations." Workshop: Renewable Energy From Woody Biomass, May 21-22, 1991. Massey University, Palmerston North, New Zealand.

State of Connecticut. 1990. "Study of the Potential Impact and Benefits of Woodburning Facilities in Connecticut." Reported in Biologue, September/October 1990.

Turhollow, A.F. Jr., Shen, S. Jr., Omek, G.E., and Heady, E.O. May 1985. "The Potential Impact of Large-Scale Biomass Production On U.S. Agriculture." Center for Agricultural and Rural Development, Report 130, Iowa State University, Ames, IA.

Turnbull, J.H. May 1991. Final Report: PG \& E Biomass Qualifying Facilities Lessons Learned Scoping Study - Phase I. Pacific Gas and Electric Company Department of Research and Development, 3400 Crow Canyon Road, San Ramon, CA.

U.S. Congress, Office of Technology Assessment. July 1990. Forest Service Planning: Setting Strategic Directions Under RPA. OTA-F-44, U.S. Government Printing Office, Washington, DC.

U.S. DOE. January 1991. Biomass Electric Technology Rationale. Solar Thermal and Biomass Power Division, Office of Solar Energy Conversion, U.S. Department of Energy, Washington, DC. Draft. $45 \mathrm{pp}$.

Wilkinson, C.F. and Anderson, H.M. 1987. Land And Resource Planning In The National Forests. Island Press, Washington, DC.

Wood, F.E., Jr. 1989. U.S. Regional Biofuel Program: Technology Transfer For Commercial Projects. Energetics, Inc., Columbia, MD.

Zinn, J.A. April 1989. "Opportunities and Limitations Associated With Using the Conservation Reserve Program (CRP)." In Agriculture, Forestry and Global Climate Change, - A Reader. Library of Congress.

\section{Biomass Fuels: Their Occurrence and Suitability}

Bockheim, J.G., Benzel, T.C., Lu, R., and Thiel, D.A. March 1988. "Sludge Increases Pulpwood Production." Biocycle. 
Braunstein, H.M., Kornegary, F.C., Roop, R.D., and Sharples, F.E. 1981. "Environmental and Health Aspects of Biomass Energy Systems." Oak Ridge National Laboratory, in Fuels From Biomass and Wastes, Klass, D.L. and Emert, G.I. eds., Ann Arbor Science Publishers, Ann Arbor, MI.

Brockway, D.G. October 1988. "Forest Land Application of Municipal Sludge." Biocycle.

Bushnell, D.J., Haluzok, C., and Dadkhah-Nikoo, A. 1989. Biomass Fuel Characterization Testing and Evaluation: The Combustion Characteristics of Selected Biomass Fuels. Report to Bonneville Power Administration under Contract No. DE-A179-88BP39 643. Oregon State University, Corvallis, OR.

Cantor, R.A. and Rizy, C.G. 1991. "Biomass Energy: Exploring the Risks of Commercialization in the United States of America." Bioresource Technology 35:1-13.

Carlson, W. 1990. "Operating Experience At a 49 MW Wood-Fired Plant." Presented at the 1990 Electric Power Research Institute Conference on Biomass for Utility Applications.

Conklin, F.S., Taylor, M., Miles, T.R., Miles, T.R., Jr., Davis, E., and McHugh, E.J. May 1991. Opportunities in Grass Straw Utilization: An Alternative Point of View. Agricultural Experiment Station Special Report 881. Oregon State University, Corvallis, OR.

Council for Agricultural Science and Technology (CAST). September 1990. Ecological Impacts of Federal Conservation and Cropland Reduction Programs. CAST Summary Report No. 117.

Crooks, J.W. April 1988. "Pennsylvania Township Grows Own Chips." Biocycle.

Environmental Risk Limited. 1991. Wood Products in the Waste Stream: Characterization and Emissions Testing Protocol Development. Contract with the New York State Energy Research and Development Authority, 1991-1992. 120 Mountain Avenue, Bloomfield, CT 06002.

Fiber Fuels Institute. 1991. Newsletter. Natural Resources Research Institute, 5013 Miller Trunk Highway, Duluth, MN 55811.

Folk R.L. and Campbell, A.G. 1991. "Physical and Chemical Properties of Hog Fuel and Fines From A Classified Logyard Waste." Proceedings of the National Bioenergy Conference, March 18-21, 1991, Coeur d'Alene, ID.

Goss, J.R. and Miles, T.R. Jr. 1989. State-of-the-Art of Rice Husk Gasification. Biomass Technology Group, University of Twente, P.O. Box 217, 7500 AE Enschede, the Netherlands.

Graham, R.L. December 1991. "Environmental Concerns Pertinent to Feedstock Production." Summary of Biomass Energy Strategies Workshop, interagency meeting held at Oak Ridge National Laboratory, Oak Ridge, TN.

Grasso, D.T. and Atkins, R.S. 1991. "The Composition of Recycled Wood Fuel: Environmental Permitting Implications." Presented to the Institute of Gas Technology Conference on Energy and Wastes. Washington, DC.

Hohman, E.H. October 1990. "Municipal Solid Waste: The SEMASS Project." Presented at the Electric Power Research Institute 1990 Conference on Biomass For Utility Applications, Tampa, FL. 
Jenkins, B. M. 1983. Systems Analysis of Biomass Utilization. Report to Pacific Gas and Electric Company and Southern California Gas Company. University of California Davis, Agricultural Engineering Department.

Lea, R. and Fredrick, D.J. April 1991. "Biomass Energy Production/Wastewater Disposal." Presented at Energy From Biomass and Wastes XV. Washington DC.

Lyons, J.K. and Kerstetter, J.D. April 1990. "Mixed Wastepaper as Fuel: Environmental, Economic and Market Assessments. WAOENG-89-60, Washington State Energy Office, 809 Legion Way SE, Olympia, WA.

Milne, T.A., Brennan, A.H., and Glenn, B.H. 1990. Sourcebook of Methods of Analysis for Biomass and Biomass Conversion Processes. Elsevier Applied Sciences, NY.

Miles, T.R., Jr. 1988. "Straw Combustion Energy Systems." Prepared for the Energy Division, Montana Department of Natural Resources and Conservation, Helena, MT.

Miles, T.R. and Miles, T.R., Jr. March 1991. Urban Wood: Fuels From Landscapers and Landfills. Presented at the National Bioenergy Conference, Coeur d'Alene, ID.

Morris, G. May 1991. The California Biomass Energy Industry in 1990: Supply, Demand, and Outlook for Biomass Fuels. Pacific Gas and Electric Company, Department of Research and Development, 3400 Crow Canyon Road, San Ramon, CA.

National Academy of Sciences. 1969. United States-Canadian Tables of Feed Composition: National Academy of Sciences, Washington, DC.

Nelson, R.G. and Schrock, M.D. 1991. "Estimation of Agricultural Crop Bioenergy Resource Availability in Kansas." Folk, R. Ed., Proceedings of the National Bioenergy Conference, Coeur d'Alene, ID, March 18-12.

Pisarik, P. March 1987. Decision Makers Guide to Crop Residue Energy Systems. Prepared by Iowa Natural Heritage Foundation for Great Lakes Regional Biomass Energy Program, Council of Great Lakes Governors, 122 West Washington Avenue, 801A, Madison, WI.

Ranney, J.W. 1991. "A Review of the Environmental Issues For Energy Crops and Biomass for Energy." Prepared for EPA contract Biomass Energy Strategies for Carbon Dioxide Mitigation in the United States. Oak Ridge National Laboratory, Oak Ridge, TN.

Ravn-Jensen, L. 1991. "Heat and Power Production From Straw, Wood and Other Biofuels in Denmark." Presented at the 6th European Conference on Biomass for Energy, Industry and Environment, Athens, Greece, April 21-27, 1991.

Solar Energy Research Institute. September 1986. The Production of Herbaceous Feedstocks For Renewable Energy. SERI/SP-273-2302. Solar Energy Research Institute, 1617 Cole Blvd., Golden, CO.

Solar Energy Research Institute. March 1990. The Potential of Renewable Energy: An Interlaboratory White Paper. SERI/TP-260-3674. Solar Energy Research Institute, 1617 Cole Blvd., Golden, CO.

Shaddock, W. October 1990. "Commercial Experience: Agricultural Wastes (Rice Hulls)." Presented at the 1990 Conference on Biomass for Utility Applications, Tampa, FL. 
Sims, R.E.H., Handford, P., and Bell, T. 1991. "Wood Fuel Supply And Utilization From Short Rotation Energy Plantations." Workshop: Renewable Energy From Woody Biomass, May 21-22, 1991. Massey University, Palmerston North, New Zealand.

State of Connecticut. 1990. "Study of the Potential Impact and Benefits of Woodburning Facilities in Connecticut." Reported in Biologue, September/October 1990.

State of Vermont. 1981. Docket No. 4450 Public Service Board Order allowing construction of the $50 \mathrm{MW}$ wood-fired electric generating station to be known as the Joseph C. McNeil Station.

Turnbull, J.H. May 1991. Final Report: PG \& E Biomass Qualifying Facilities Lessons Learned Scoping Study_ Phase I. Pacific Gas and Electric Company Department of Research and Development, 3400 Crow Canyon Road, San Ramon, CA.

USDA-U.S.DOE. 1991. Memorandum of Understanding.

Wilhelm, D.J. and Simbeck, D.R. 1990. "The California FBC Boiler Story: A Status Report." Paper presented at the Council of Industrial Boiler Owners (CIBO) Sixth Annual Conference, December 9-11, 1990, Harrisburg, PA.

Wright, L.L. and Ehrenshaft, A.R. 1990. Short Rotation Woody Crops Program: Annual Progress Report for 1989. Oak Ridge National Laboratory Report No. ONRL-6625, Oak Ridge National Laboratory, Oak Ridge, TN.

Wright, L.L. 1989. "Commercialization Of Short-Rotation Intensive Culture Tree Production in North America." In Energy From Biomass and Wastes XIII, Institute of Gas Technology, Chicago, IL.

Wright, L.L. October 1990. "Role of New Wood Energy Crops in Mitigation of Fossil $\mathrm{CO}_{2}$ Emissions." Presented at the EPRI 1990 Conference on Biomass For Utility Applications, Tampa, FL.

\section{Environmental Implications of Increased Biomass Use}

Adler, M.J. and Schwengle, P. August 1991. "Issues in Developing a Biomass Energy Strategy for Reducing Greenhouse Gas Emissions." In Proceedings of the International Solar Energy Society, Solar World Congress.

Anderson, E.W. October 1990. "Tips on Initiating a Coordinated Plan." Rangelands 12 (5).

Anderson, E.W. and Baum, R.C. May-June 1987a. "Coordinated Resource Management Planning: Does It Work?" Journal of Soil and Water Conservation 42 (3).

Anderson, E.W. and Baum, R.C. 1987b. "How to Do Coordinated Resource Management Planning." Journal of Soil and Water Conservation, 43 (3).

Barnett, P.E., Brooks, R.T., Curtin, D.T., and McCarthy, D.M. 1985. Assessment of Potential Biomass Energy Impacts on the Forest Resource of the 201 County Tennessee Valley Authority Region. TVA/ONRED/LER-85/16. Tennessee Valley Authority, Chattanooga, TN.

Biologue. February/March 1990. "Can Trees Protect Water Supplies?" Report of Lily Lake Project, Iowa State University. 
Bohac, C.E. 1986. Integrated Environmental Assessment of Biomass for Energy. TVA/ONRED/AWR85/9. Tennessee Valley Authority, Chattanooga, TN.

Bonneville Power Administration. February 1989. Pacific Northwest and Alaska Regional Bioenergy Program, Yearbook, DOE/BP-1179, Bonneville Power Administration, Portland, OR.

Braunstein, H.M., Kornegary, F.C., Roop, R.D., and Sharples, F.E. 1981. "Environmental and Health Aspects of Biomass Energy Systems." Oak Ridge National Laboratory, in Fuels From Biomass and Wastes, Klass, D.L. and Emert, G.I., eds. Ann Arbor Science Publishers, Ann Arbor, MI.

Broussard, L. 1991. "Life List U.S.A.: The Endangered and Threatened Species of the U.S.A." Wilderness, 54:193, Summer.

Brown, G.W. 1989. Forestry and Water Quality, Second Edition. Oregon State University, Corvallis, OR.

Brown, M.D., Baker, E.G., and Mudge, L.K. 1986. Environmental Design Considerations for Thermochemical Biomass Energy. Pacific Northwest Laboratory, Richland, WA.

Burnet, P. 1987. "Environmental Impacts From Advanced Technology Residential Combustors." Presented at the Annual Meeting, Air Pollution Control Association.

Cantor, R.A. and Rizy, C.G. 1991. "Biomass Energy: Exploring the Risks of Commercialization in the United States of America." Bioresource Technology, 35:1-13.

Campbell, A.G. March 1991. "Wood Ash Disposal and Utilization." Presented to the National Bioenergy Conference, Coeur d'Alene, ID.

Center for the Conservation of Genetic Diversity. 1991. USDA Forest Service, Pacific Southwest Forest Range and Experiment Station, Berkeley, CA.

Cline, M.L., Hoffman, B., and Cyr. M. 1990. Evaluation of Residual Stand Damage Following Whole-Tree Partial Cutting in Northern Forest Types. Report No. DOE/OR/21389-28. CONEG Policy Research Center, Inc. Washington, DC.

Cook, J.H., Beyea, J., Keeler, K.H. March 1991. "Preserving Biological Diversity in the Face of LargeScale Demands for Biofuels." Audubon Society. Presented at the Energy From Biomass and Wastes XV, Washington, DC.

Council on Environmental Quality. 1989. Environmental Trends. U.S. Government Printing Office, Washington, DC.

Council of Northeastern Governors, April 1989. Northeast Regional Biomass Program Five Year Report: 1983-1988. CONEG Policy Research Center, Inc., 400 N. Capitol Street, Suite 382, Washington, DC.

DiNovo, S.T., Ballantyne, W.E., Curran, L.M., Baytos, W.C., Duke, K.M., Cornaby, B.W., Mathews, M.C., Ewing, R.A., and Vigon, B.W. October 1978. Preliminary Environmental Assessment of Biomass Conversion to Synthetic Fuels. Battelle Columbus Laboratories EPA$600 / 7 / 78 / 204$, for U.S. EPA. 
Elliott, P. and Booth, R. 1990. "Sustainable Biomass Energy." Summary based on papers presented to the "World Renewable Energy Congress," Reading University, September 1990; and the UNIDO/ Institute of Energy Workshop on Biomass Thermal Processing Projects. Shell International Petroleum Company, Ltd., Shell Centre, London SE1 7NA, England.

Envirosphere. 1982. Program Negative Declaration for the Biomass Conversion Demonstration Program. Report for the California Energy Resources Conservation and Development Commission, Contract No. 500-81-037, California Energy Commission, Sacramento, CA.

Folk R.L. and Campbell, A.G. 1991. "Physical and Chemical Properties of Hog Fuel and Fines From A Classified Logyard Waste." Proceedings of the National Bioenergy Conference, March 18-21, 1991, Coeur d'Alene, ID.

Geron, C. 1991. Report on Forestry and Global Climate Mitigation. Global Warming and Control Branch, Global Warming and Emissions and Control Division (MD-63) U.S. EPA Office of Research and Development, Air and Energy Engineering Research Laboratory, Research Triangle Park, NC.

Graedel, T.E. 1990. "Regional Environmental Forces: A Methodology for Assessment and Prediction." In Helm, J.H., ed., Energy Production, Consumption and Consequences. National Academy Press, Washington, DC.

Graham, R.L. December 1990. "Environmental Concerns Pertinent to Feedstock Production." Summary of Biomass Energy Strategies Workshop, interagency meeting held at Oak Ridge National Laboratory, Oak Ridge, TN.

Grasso, D.T., Atkins, R. 1991. "The Composition of Recycled Wood Fuel: Environmental Permitting Implications." Presented at the Energy From Biomass and Wastes XV, Washington, DC.

Greber, B.J., Johnson, K.N., and Lettman, G. 1990. "Conservation Plans for the Northern Spotted Owl and Other Forest Management Proposals in Oregon: The Economics of Changing Timber Availability," Papers in Forest Policy 1, Forest Research Laboratory, Oregon State University, Corvallis, OR.

Hale, A.M., Marshall, W.D., and Scurry, J.D. 1991. GIS Policy Research. Geo Info Systems, Aster Publications, Eugene, OR.

Helm, J.L. ed. 1990. Energy: Production, Consumption and Consequences. National Academy Press, Washington, DC.

Herrera, G., Jordan, H., Zimmerman, G., Leonard, R., and Morgenster, J. April 1989. "Source Testing of Biomass Co-Generation Facilities." California Air Resources Board. In Proceedings, International Conference On Municipal Waste Combustion, Hollywood, FL, Environment Canada and EPA.

Howard, J.O. October 1990. Biomass Estimates for Five Western States. Prepared by USDA Forest Service, Pacific Northwest Research Station for the Pacific Northwest and Alaska Regional Bioenergy Program, U.S. DOE. 
Ice, G.G., Beschta, R.L., Craig, R.S., and Sedell, J.R. 1989. "Riparian Protection Rules for Oregon Forests." In Proceedings of the California Riparian Systems Conference: Protection, Management, and Restoration for the 1990's. General Technical Report PSW-110. USDA Forest Service, Pacific Southwest Forest and Range Experiment Station, Berkeley, CA.

Johnson, J.E., Poppoe, P.E., Mroz, G.D., and Payne, N.F. March 1987. Environmental Impacts of Harvesting Wood For Energy; Great Lakes Regional Biomass Energy Program. DOE/OR/21390-T16.

Jones, R.K. 1990. Integrated Consulting Group, Salt Lake City, UT. Personal Communication.

Kennel, R.P. 1984. "Wood-fired Power Production: Financial, Legal, Institutional and Environmental Issues." In Energy From Biomass: Building on a Generic Technology Base. Proceedings of the Third Technical Review Meeting, November 27-29, Argonne National Laboratory publication ANL/ CNSV-TM-157, Argonne, IL.

Kimmins, J.P., Kurz, W.A., Scoullar, K.A., Apps, M.J., and Comeau, P.G. 1989. Forcyte-11: A Flexible User-Controlled Microcomputer Simulation Model With Which To Examine Biomass Yields of Alternative Forestry or Agroforestry Management Systems. Seventh Canadian Bioenergy R\&D Seminar, April 24-26, 1989, Ottawa, Ontario. Bioenergy Development Program, Energy Mines and Resources.

Land and Water. January 1991. "Local Cooperation Working to Improve Water Quality."

Legget, J. 1990. Global Warming: The Greenpeace Report. Oxford University Press, New York.

Little, S.N. and Waddell, D.R. 1986. "Environmental Impacts of Intensive Utilization of Lodgepole Pine For Energy." In Biofuels and Municipal Waste Technology Research Program Summary FY 1986, Office of Renewable Technologies, U.S. Department of Energy, Washington, DC.

Maser, C., Tarrant, R.F., Trappe, J.M., and Franklin, J.F. 1988. From The Forest To The Sea: A Story of Fallen Trees. General technical report PNW-CTR-229. Pacific Northwest Research Station, USDA Forest Servce, Portland, OR.

Menke, J.W. April 1979. Long-Term Nutrient Balance Consequences of Wildland Biomass Harvesting for Energy from Forest and Shrubland Ecosystems: A Preliminary Proposal. Proposal to the Department of Energy.

Miles, T.R., Craig, L.S., and Greene, W.T. October 1984. Guide to Oregon's Environmental Permits for Biomass Energy Projects. Prepared for the Oregon Department of Energy and the Pacific Northwest and Alaska Bioenergy Program.

Muir, P.S. January 1991. "Fogwater Chemistry in a Wood-burning Community, Western Oregon." Journal of Air and Waste Management, 41(1):32.

Munasinghe, M. 1989. "Environmental and Energy Resource Management Analytical Framework and Policy Options." Proceedings of the 9th Miami International Congress on Energy and Environment. University of Miami, Coral Gables, FL.

Musselman, R.C. and Fox, D.G. June 1991. "A Review of the Role of Temperate Forests in the Global $\mathrm{CO}_{2}$ Balance." Journal of Air and Waste Management, 41 (6):798. 
Noteware, W.D. 1989. "Programs On Energy From Biomass And Wastes Funded By the California Energy Commission." In Energy From Biomass and Wastes XIII. Institute of Gas Technology, Chicago, IL.

Nakamura, G. 1990. "Notes on the Mechanized Harvesting Workshop, June 20, 1990, Shingletown, CA," University of California, Berkeley.

O'Leary, Philip R. 1988. "Environmental Risk Assessment of Biomass Fueled Energy Production Systems." Energy From Biomass and Wastes XII. Institute of Gas Technology, Chicago.

Oregon Department of Energy. January 1991. Fourth Biennial Plan. Salem, OR.

Overend, R.P. June 1991. Report on the conference: Technologies For A Greenhouse-Constrained Society, Oak Ridge National Laboratory, Oak Ridge, TN.

Ranney, J.W. 1992. "A Review of the Environmental Issues for Energy Crops and Biomass for Energy." Prepared for EPA contract Biomass Energy Strategies for Carbon Dioxide Mitigation in the United States. Oak Ridge National Laboratory, Oak Ridge, TN.

Sampson, R.N. 1991. "Biomass Opportunities in the United States To Mitigate The Effects of Global Warming." American Forestry Association. Presented at Energy from Biomass and Wastes, Institute of Gas Technology, Chicago, IL.

Sachs, D., Kimmins, J.P., and Apps, M.J. 1989. "Using FORCYTE-11 To Examine The Potential Effects of Intensive Management And Increased Utilization On Long Term Productivity Of Douglas Fir Forests." Presented at the Seventh Canadian Bioenergy R\&D Seminar, April 24-26, 1989, Ottawa, Ontario. Bioenergy Development Program, Energy Mines and Resources.

Solar Energy Research Institute. March 1990. The Potential of Renewable Energy: An Interlaboratory White Paper. SERI/TP-260-3674. Solar Energy Research Institute publication, 1617 Cole Blvd., Golden, CO.

Smith, C.T., McCormac, M.L., Hornbeck, J.W., and Martin, C.W. 1986. "Nutrient and Biomass Removals From A Red Spruce-Balsam Fir Whole-Tree Harvest." Canadian Journal of Forest Products, 16:2.

Smith, W.H. 1987. "Environmental Factors and Biomass Energy Development." In Biomass, D.O. Hall and R.P. Overend, eds. John Wiley \& Sons Ltd, NY.

Snider, M.D. and Miller, R.F. 1985. "Effects of Tractor Logging On Soils and Vegetation in Eastern Oregon." American Journal of Soil Science 49:5.

Strauss, S.D. May 1991. "Water Management For Reuse/Recycle." Power.

Tennessee Valley Authority. 1989. Nero \& Associates. 1986. Permits, Regulations for Biomass Energy Facilities in the Southeast. Prepared under TVA Contract TV-67243A, U.S. Department of Energy, Tennessee Valley Authority.

Thomas, J.W. 1990. "Wildlife." In American Forestry Association, Natural Resources for the 21st Century, Island Press, Washington, DC.

Torsten, I. January 1991. "Nutrition and Growth of Forest Trees." TAPPI Journal. 
Turnbull, J.H. May 1991. Final Report: PG \& E Biomass Qualifying Facilities Lessons Learned Scoping Study - Phase I. Pacific Gas and Electric Company Department of Research and Development, 3400 Crow Canyon Road, San Ramon, CA.

Turner, S.M. 1991. "The Impact of the 1990 Clean Air Act Amendments on Biofuels Usage and Waste-to-Energy Systems." Presented to the 1991 IGT Energy From Biomass and Wastes, Washington, DC.

Vranizan, J.M., Neild, P., Craig., L.S., Brown, L.F., Gay, R.L., and Dezeeuw, R. 1987. Biomass Energy Project Development Guidebook. Bonneville Power Administration Pacific Northwest and Alaska Regional Bioenergy Program, Portland, OR.

Waring, R.H. and Schlesinger, W.H. 1985. Forest Ecosystems. Academic Press, Inc., Orlando, FL.

Wellman, E.A. and Butchino, E.C. March 1989. "Wood Fired Boiler Emissions and Emission Factors." BWR Associates. Presented at the Air and Waste Management Association International Specialty Conference on Combustion and the Environment, Seattle, WA.

Wilhelm, D.J. and Simbeck, D.R. 1990. "The California FBC Boiler Story: A Status Report." Paper presented at the Council of Industrial Boiler Owners (CIBO) Sixth Annual Conference, December 9-11, 1990, Harrisburg, PA.

Wright, L.L., Graham, R.L., and Turhollow, A.F. 1990. "Short-Rotation Woody Crop Opportunities to Mitigate Carbon Dioxide Buildup." U.S. DOE CONF-9005261-1. Presented at the North American Conference on Forestry Responses to Climate Change.

USDA Forest Products Laboratory. August 1990. Forest/Energy News, J. Zerbe, ed. 2 (1).

U.S. Congress, Office of Technology Assessment. February 1991. Changing by Degrees: Steps To Reduce Greenhouse Gases: Summary. OTA-O-483, U.S. Government Printing Office, Washington, DC. 


\begin{tabular}{|c|c|c|c|}
\hline & $\begin{array}{l}\text { 1. NREL Report No. } \\
\text { TP-230-4633 }\end{array}$ & $\begin{array}{l}\text { 2. NTIS Accession No. } \\
\text { DE92001219 }\end{array}$ & 3. Recipient's Accession No. \\
\hline \multirow{2}{*}{\multicolumn{3}{|c|}{$\begin{array}{l}\text { 4. Title and Subtitle } \\
\text { Environmental Implications of Increased Biomass Energy Use: } \\
\text { Final Report }\end{array}$}} & $\begin{array}{l}\text { 5. Publication Date } \\
\text { March } 1992\end{array}$ \\
\hline & & & 6. \\
\hline \multicolumn{3}{|c|}{$\begin{array}{l}\text { 7. Author(s) } \\
\text { T.R. Miles Sr., and T.R. Miles, Jr. }\end{array}$} & $\begin{array}{l}\text { 8. Performing Organization Rept. } \\
\text { No. }\end{array}$ \\
\hline \multirow{2}{*}{\multicolumn{3}{|c|}{$\begin{array}{l}\text { 9. Performing Organization Name and Address } \\
\text { Thomas R. Miles } \\
\text { Consulting Design Engineers } \\
5475 \text { S. W. Arrowwood Lane } \\
\text { Portland, OR } 97225\end{array}$}} & $\begin{array}{l}\text { 10. ProjectTask/Work Unit No. } \\
\text { BP111010 }\end{array}$ \\
\hline & & & $\begin{array}{l}\text { 11. Contract (C) or Grant (G) No. } \\
\text { (C) } \\
\text { (G) }\end{array}$ \\
\hline & \multirow{2}{*}{\multicolumn{2}{|c|}{$\begin{array}{l}\text { Sponsoring Organization Name and Addr } \\
\text { National Renewable Energy Laboratory } \\
1617 \text { Cole Boulevard } \\
\text { Golden, CO } 80401 \\
\quad \text { and } \\
\text { Pacific Gas and Electric Company } \\
3400 \text { Crow Canyon Road } \\
\text { San Ramon, CA } 94583\end{array}$}} & $\begin{array}{l}\text { 13. Type of Report \& Period } \\
\text { Covered } \\
\text { Technical report }\end{array}$ \\
\hline & & & 14. \\
\hline \multicolumn{4}{|c|}{ 15. Supplementary Notes } \\
\hline & \multicolumn{3}{|c|}{$\begin{array}{l}\text { Abstract (Limit: } 200 \text { words) } \\
\text { Increased use of renewable biomass for electric power production will depend both on supply availability and } \\
\text { on sustainability. An approximate short-term measure of sustainability is the technology's environmental } \\
\text { impact. This report examines all elements of the biomass to electric power production cycle in terms of the } \\
\text { known environmental impacts associated with currently available technology. The current literature base was } \\
\text { surveyed and input was solicited from recognized leaders in the biomass to energy community. It identifies } \\
\text { areas that need increased research and monitoring to ensure the sustainability of the renewable biomass } \\
\text { resource. }\end{array}$} \\
\hline \multicolumn{4}{|c|}{$\begin{array}{l}\text { 17. Document Analysis } \\
\text { a. Descriptors } \\
\text { biomass, electric power production, alternative energy, environment } \\
\text { b. Identifiers/Open-Ended Terms }\end{array}$} \\
\hline \multirow[t]{2}{*}{18.} & \multirow{2}{*}{\multicolumn{2}{|c|}{$\begin{array}{l}\text { Availability Statement } \\
\text { National Technical Information Service } \\
\text { U.S. Department of Commerce } \\
\text { 5285 Port Royal Road } \\
\text { Springfield, VA } 22161\end{array}$}} & $\begin{array}{l}\text { 19. No. of Pages } \\
53\end{array}$ \\
\hline & & & $\begin{array}{l}\text { 20. Price } \\
\mathrm{A} 04\end{array}$ \\
\hline
\end{tabular}

